\title{
IMPACT TRANSACTION: LAWYERING FOR THE PUBLIC GOOD THROUGH COLLECTIVE IMPACT AGREEMENTS
}

\author{
Patience A. Crowder*
}

\section{INTRODUCTION}

Impact transaction effectuates social change. A new theoretical concept "impact transaction" is a term I coined to describe a strategy of transactional advocacy in the public interest that, like impact litigation, has the potential for making large-scale social change. ${ }^{1}$ In cities such as Baltimore, Detroit, and Ferguson, inequities are profound and historically underserved communities remain in need of transformation despite high philanthropic interest is high and engagement from private, government, and non-profit sectors. ${ }^{2}$ These communities urgently require impact transaction to capitalize on social momentum while protecting community interests.

As the country continues to recover from the effects of the Great Recession, community leaders interested in large-scale social change are seeking innovative approaches by which to effectuate such change against the reality of shrunken public sector resources, the limitations of judicial remedies, and the political nature of public policy. Today, cross-sector coalitions are collaborating to address the most persistent and pernicious societal ills in communities across the United States. For example, in Indianapolis, the Community-Wide Plan to End Domestic Violence is a coalition of social service providers, public safety officials, government agencies, hospitals, and faith communities working to end domestic violence in Central Indiana. ${ }^{3}$ To improve the quality of life of youth in New Orleans, the Laureus Sport for Good Foundation Model City Initiative awarded $\$ 1.5$ million in grants to a collective of youth development organizations

* Assistant Professor of Law, University of Denver Strum College of Law; B.A, Georgetown University; J.D., Rutgers University School of Law-Newark. I thank Rachel ArnowRichman, Susan Bennett, Scott Cummings, Eric Franklin, Kate Kruse, Spencer Rand, and Nantiya Ruan for their very thoughtful comments on earlier drafts as well as the participants at the following workshops: Legal Scholarship 4.0, Tackling the Urban Core Puzzle, 2015 Clinical Law Review Writers' Workshop, 2015 AALS Conference on Clinical Legal Education, and $14^{\text {th }}$ Annual Transactional Clinical Conference. I also thank Allie Moore and Cameron Hunter for their very diligent and creative research.

1. I thank my University of Denver colleague and civil rights advocate, Professor Nantiya Ruan, who helped me coin this phrase through our discussions on impact litigation, transactional work, and public interest law.

2. See, e.g., Suzanne Perry, Detroit Tests What Foundations Can Do To Rescue Troubled Cities, Chron.Philanthropy (Oct. 20, 2013), https://philanthropy.com/article/Can-PhilanthropyRescue/154175 [https://perma.cc/8HZX-FTGQ].

3. See CWP 3.0: Collective Impact in Indianapolis, Community Solutions, http://www. communitysolutionsinc.net/featured/cwp-3-0-collective-impact-in-indianapolis [https://perma.cc/E3SG-R94R] (last visited Feb. 1, 2016).

http://dx.doi.org/10.18060/4806.0101 
collaborating over a three-year period to create a sport for development plan. ${ }^{4}$ In Detroit, the Detroit Collective Impact Initiative - Pathway to Education \& Work is a coalition that includes a nonprofit organization fighting generational poverty for decades, a nonprofit organization dedicated to economic vitality, the Michigan Virtual University, and McDonald's, which work together to strengthen Detroit's workforce by engaging disconnected adults and out-of-school youth with online education and training programs that provide high school diplomas and career training. ${ }^{5}$ These are collective impact initiatives.

"Collective impact" is relatively new terminology emerging out of the philanthropic community for describing structured collaboration among parties who are focused on alleviating a particular social ill. ${ }^{6}$ Branded as "a way to better utilize resources and identify effective practices,", collective impact initiatives intentionally recruit a group of actors from diverse industries and with diverse perspectives to focus on a specific social ill. ${ }^{8}$ These are entrepreneurial enterprises that prioritize the function of fluidity over form. ${ }^{9}$ In many respects, collective impact participants "agree to agree" over the course of an ongoing relationship built around the pursuit of social change. This approach raises important questions about authority and responsibility such as "[h]ow and by whom are strategic goals determined? Who gets to participate and what are the requirements for participation? How are initiatives held accountable and by whom?" 10 The success of any given initiative depends upon the answers to these and similar questions. For example, a collective impact initiative structured around a common agenda to increase arts-related educational programs at junior high schools throughout a city could become undone when the participants later decide to hire afterschool art instructors, but no participant in the initiative is willing or actually has the capacity to add these instructors on its payroll.

By highlighting the value of agreements, particularly written contracts, this Article presents two new lawyering tools for effectuating large-scale social change. Until now, there has been no legal scholarship about collective impact. This Article is the first to consolidate and analyze the collective impact strategy and to give any treatment to collective impact agreements, and it does so by

4. See Laureus USA Announces Inaugural Grantees for the New Orleans Model City Initiative, LAUREUS (Nov. 25, 2014), http://www.laureus.com/news/laureus-usa-announcesinaugural-grantees-new-orleans-model-city-initiative [https://perma.cc/36KJ-5G2S].

5. See Developing Detroit's Talent Through Collective Impact, INSPECTOR PROJECT (Jun. 29, 2015), http://intersector.com/cengage-learning-developing-detroits-talent-through-collectiveimpact/ [https://perma.cc/7AB2-ZJAK].

6. See Collective ImPACt F., http://collectiveimpactforum.org [https://perma.cc/D4HZXET9] (last visited Feb. 28, 2016).

7. Kara BiXby, Collective Impact: How Backbone Organizations Influence Change Without Formal Authority (2014), available at http://web.augsburg.edu/sabo/ CollectiveImpactBixby.pdf [https://perma.cc/9GWK-7ES7].

8. Id.

9. Id.

10. Id. 
presenting collective impact in the larger context of impact transaction, a transactional, non-litigation strategy for social change. This Article creates the foundation for a new space where transactional lawyers deploy problem-solving skills in partnership with collective impact initiatives to effectual social change through written agreements.

Collective impact processes are in the early stages of development, and barriers to effectiveness are emerging. The absence of a contractual framework is one of these barriers. Typical collective impact initiatives are managed through the strength of the parties' relationships and not through a written agreement. As such, this Article argues that critical questions such as those asked above and the collective impact process are best understood through a relational contract context, a contract law theory that looks beyond the parties' privity to a contract to consider the relationships among the parties and their intent as well, and memorialized in a written agreement between the members of collective impact initiatives - which is currently the exception and not the norm. More specifically, this Article begins to lay the groundwork for impact transaction, large-scale social change by agreement, by building a framework for drafting relational contracts by examining the collective impact process. In advocating for impact transaction, this Article's unique contribution blends the philanthropic strategy of collective impact with the theoretical underpinnings of relational contract theory to offer practical contract drafting strategies for memorializing collective impact initiatives. Such building out of the collective impact contracting process will enhance the likelihood of the sustainability of collective impact initiatives and impact transaction strategies, more generally, through the replication and adaptation of the model. ${ }^{11}$ Part I introduces the concept of impact transaction and presents the boundaries of impact transaction as a transactional tool for largescale social change by examining the legal and social significance of "agreement" as a foundational component of impact transaction strategy. Part II introduces collective impact, details the collective impact framework, assesses the value and risks of the collective impact process, and situates collective impact as impact transaction tool. Delving into the value of agreement identified in Part I, Part III grounds collective impact in relational contract theory to capture and explain its potential for using agreements and relationships as tools for social change. To reinforce the timely utility of this Article, Part IV presents drafting principals for collective impact initiatives by exploring the utility of a standard form collective impact term sheet. The Article then concludes by exploring counterarguments, predictions, and potential next steps for collective impact as an impact transaction strategy.

11. This Article is the first of a series of four. The second article will detail specific contract law issues inherent in the collective impact process and propose a system for papering these initiatives by presenting a form term sheet and collective impact agreement. The third article will examine the developing collective impact governance structure to explore ideas of corporate governance and community participation in collective impact initiatives. Then, the fourth article in the series will explore whether collective impact can be scaled up as a tool in the regional equity movement. 


\section{Promoting Social Change Through Impact Transaction}

Impact litigation is the legal tool traditionally associated with public interest or social change lawyering. ${ }^{12}$ The concept of impact litigation is a familiar term: judicial adjudication of cases that have the potential to impact conditions broadly for many similarly-situated people or to highlight a particular issue. Early civil rights advocates employed impact litigation strategies to vindicate rights and address injustice through judicial opinion. ${ }^{13}$ In turn, impact litigation strategists hope those judicial decisions spur broader legal change through legislative action. ${ }^{14}$ The National Association for the Advancement of Colored People's (NAACP) impact litigation campaigns come easily to mind such as, most famously, its efforts to abolish segregated education by bringing Brown v. Board of Education. ${ }^{15}$

At its core, impact litigation works to reform institutions, including both public governmental agencies, such as those agencies involved with education or environmental protection, and private entities, such as corporate employers. ${ }^{16}$ Impact litigation protects the interests of individuals in the suit while hoping those actions eventually advance the public good. But as with all litigation, private adjudication comes with high costs and risks and may take years to come to fruition. ${ }^{17}$

Legal commentators have aptly and thoroughly described the risks associated with litigation and presented alternate dispute resolution (ADR) choices such as negotiation, mediation, and arbitration as alternative to address litigation's negative attributes. ${ }^{18}$ In essence, ADR involves agreement: parties agreeing to resolve their dispute, either by themselves (negotiation), with the aid of a thirdparty neutral (mediation), or by party appointment of a decision maker who has ultimate authority to determine the resolution outcome (arbitration) ${ }^{19}$ However,

12. Alan Chen \& Scott Cummings, Public Interest Lawyering 201 (Wolters Kluwer 2012).

13. See generally Richard Kluger, Simple Justice: The History of Brown V. BOARD of EDUCATION AND Black America's Struggle for Equality (Vintage Books 1975).

14. Id.

15. 347 U.S. 483 (1954); see generally KLUGER, supra note 13 (providing an overview of the events and strategy surrounding the seminal school desegregation decision); MARK V. TUSHNET, The NAACP's Legal Strategy Against Segregated Education, 1925-1950 1 (2d ed. 1987) (citing CHEN \& CUMMINGS, supra note 12, at 204).

16. See, e.g., Lori Turner, Using Impact Litigation as a Tool for Social Change: Jimmy Doe: A Case Study, Harv. C.R.-C.L. L. Rev. (Aug. 10, 2010), http://harvardcrcl.org/using-impactlitigation-as-a-tool-for-social-change-jimmy-doe-a-case-study-by-lori-turner [https://perma.cc/5F9W-CB65].

17. See id.

18. See, e.g., Carrie J. Menkel-Meadow, Mediation: Practice, Policy, and Ethics (2d ed. 2013).

19. Many advocates involved in these types of dispute resolution avoid the term "alternative" 
those ADR efforts have little to no impact on the broader social good because of its singular focus on providing relief to the private parties engaged in the resolution of individual problems. ${ }^{20}$ This Article builds upon the ADR critique of litigation to demonstrate the value of agreement to build relationships. What if the core of ADR - agreement - was able to promote social change - the core of impact litigation? Impact transaction is that answer.

\section{A. Impact Transaction as a Strategy for Social Change}

As a strategy for legal reform, impact litigation can lay claim to much success. From prisoner rights ${ }^{21}$ to breaking gender glass ceilings in corporate America, ${ }^{22}$ private adjudication can affect the rights of litigants, including individuals and classes, as well as bring about change in judicial precedent that can positively affect future litigants in future cases. ${ }^{23}$ The hope is judicial treatment will also spur greater policy change.

This Article does not purport to replace impact litigation as a strategy for social change with impact transaction. Impact transaction is presented as an alternative to impact litigation just as ADR emerged as an alternative to litigation. Moreover, the descriptions below are not intended to ignore the nuances inherent in transactional or litigation practice but to suggest that some social problems may be more effectively challenged through transactional practice than litigation. By definition, litigation comes with significant disadvantages. The following outlines four major disadvantages of impact litigation and counters those risks with implementing change through transaction and agreement.

1. The Challenge of Implementing Judicial Decisions.-A court decision applauded by social justice advocates does not necessarily lead to the sought after social justice outcome. Judicial decisions do not guarantee desired outcomes - they make those outcomes possible but do not ensure implementation of any programs. Alternatively, judicial opinions may be narrow in scope, applicable only to a specific litigated issue. Lack of mechanisms for implementation or narrowly defined scopes of applicability can work against the social justice outcomes pursued by those who bring impact litigation suits. For example, despite Brown, schools are more segregated today than they were when Brown was decided. ${ }^{24}$ Notwithstanding Price Waterhouse, legislative action in the form of the Lilly Ledbetter Fair Pay $\mathrm{Act}^{25}$ was still necessary to address the

dispute resolution, and prefer the title "dispute resolution." By rejecting the term "ADR," advocates resist attributing the value of these processes as being solely in relation to litigation.

20. Although there can be class arbitration, ADR may often lead to confidential private resolution without precedent or public scrutiny.

21. See, e.g., Turner v. Safley, 482 U.S. 78 (1987).

22. See, e.g., Price Waterhouse v. Hopkins, 490 U.S. 228 (1989).

23. See Chen \& Cummings, supra note 12 , at 215.

24. Nikole Hannah-Jones, Segregation Now, ProPublica (Apr. 16, 2014), https://www. propublica.org/article/segregation-now-full-text [https://perma.cc/A2XG-2V6U].

25. Lilly Ledbetter Fair Pay Act of 2009, Pub. L. No. 111-2, 125 Stat. 5 (2009). 
gender gap in wages but, on average, women workers are paid seventy-seven cents for every dollar a male worker receives. ${ }^{26}$ Likewise, although Obergefell affirmed the right of gay and lesbian couples to marry, advocates still have work to do with respect to a host of other challenges for nontraditional families, including the ability of same-sex couples to adopt children. ${ }^{27}$

Impact litigation has undisputedly advanced social change in a variety of arenas. Impact transaction, however, has the potential to promote equally important but structurally distinct types of social change-where individual rights are not necessarily implicated. ${ }^{28}$

2. The High Cost of Litigation as Compared to the Lower Cost of Transaction.-First, like all litigation, impact litigation is costly. Litigation requires high monetary costs and a significant investment of time and energy by the parties and advocates. There are both direct expenses, such as attorney's fees, trial fees, and expert witness fees, and indirect expenses associated with preparing for cases and interacting with lawyers and courts. ${ }^{29}$ Through engaging in the first large-scale empirical study of litigation and its costs, a team of well-respected socio-legal scholars analyzed the attendant costs of litigation and although unwilling to judge litigation costs as "excessive," they found significant and diverse monetary costs paid by the parties, even when excluding non-monetary "internal" effects such as "psychological costs for which no dollar figure is available." $" 30$ There are nonmonetary costs too. Other scholars have noted the "cost" of litigation includes the "drain of resources from potentially more effective methods of social activism" ${ }^{31}$ such as "multi-issue grass-roots associations of sustained allegiance." 32

Transaction, by contrast, alleviates many of these resource drains. ${ }^{33}$ "Rather than dealing with disputes, [a transactional lawyer] architects relationships." ${ }^{34}$

26. Laura Bassett, Women Still Earned 77 Cents on Men's Dollar in 2012: Report, HufFInGTON Post (Sept. 17, 2013), http://www.huffingtonpost.com/2013/09/17/gender-wagegap_n_3941180.html [https://perma.cc/A64M-PJ8D].

27. Obergefell v. Hodges, 135 S. Ct. 1039 (2015).

28. See generally Patience A. Crowder, Interest Convergence as Transaction?, 75 U. PITT. L. REV. 693 (2014).

29. See, e.g., David M. Trubek et al., The Costs of Ordinary Litigation, 31 UCLA L. REv. 72, 91-92 (1983).

30. Id. at 120 (citing William L.F. Felstiner, Influences of Social Organization on Dispute Processing, 9 L. \& SOC'Y REV. 63, 80 n.23 (1974)).

31. Chen \& Cummings, supra note 12, at 225 (citing Michael W. McCann, Taking Reform Seriously: Perspectives on Public Interest Liberalism 200 (Cornell Univ. Press 1987); Gerald N. Rosenberg, The Hollow Hope: Can Courts Bring About Social Change? 339 (1st. ed. 1991)).

32. McCANn, supra note 31, at 200; see infra Part III (discussing collective impact).

33. To be sure, transactions have costs, but these are generally anticipated costs connected to the business operations of the parties and, as such, accounted for in the structure of the transaction.

34. Rachel S. Arnow-Richman, Employment as Transaction, 39 Seton Hall L. Rev. 447, 
Transaction building is without the attendant costs of trial fees, witness fees, and preparing to succeed in the adversarial process. ${ }^{35}$ Instead, the costs include the time spent coming to an agreement, which itself is part of the justice-seeking outcome.$^{36}$ As the architects of the cost of litigation study witnessed, litigation is most effective when "bargaining and settlement are the prevalent and, for plaintiffs, perhaps the most cost-effective activity that occurs when cases are filed." ${ }^{, 37}$ In other words, transaction and relationship building are the most effective parts of litigation.

3. Litigation Determines Winners and Losers, While Transaction Is Grounded in Collaboration.-Next, courts determine the outcome of impact litigation; whether the litigants seeking relief will be successful is solely within judicial discretion. The judicial system is an adversarial one where one party "wins" and the other party "loses." In order for impact litigation to have lasting social change, judges must recognize the policy implications at play in their decisions and be willing to address those issues head on by providing guidance for implementation. ${ }^{38}$ Given the uncertainty inherent in that premise, Professors Chen and Cummings opined "courts are potentially unstable and unreliable institutions for sustainable reform." $" 39$

In stark contrast to litigation, transaction is not initiated by allegations of harm from one party against another. Transaction, as a mechanism for building relationships, is not conflict based. ${ }^{40}$ Therefore, the paradigm of winners versus losers is much less prevalent. Moreover, as part of the facilitation in negotiation and mediation, transaction is premised on a "win-win" relationship. ${ }^{41}$ One can imagine transaction as the process of formalizing the outcome that the parties themselves determine from engaging in negotiation or mediation. In that way, transaction is the polar opposite of litigation: instead of a "higher" power passing judgment, the parties self-determine their destiny. In that framework, no one loses. ${ }^{42}$

456 (2009).

35. Trubek et al., supra note 29, at 91-92.

36. Id. at 91 .

37. Id. at 122 .

38. See Joel Handler, Social Movements and the Legal System: A Theory of LaW Reform And Social Change 1 (ACAD. Press 1978).

39. CHEN \& CuMmings, supra note 12, at 225.

40. See, e.g., Christine Liyanto, The Discrete, the Relational, the Selfish, and the Societal: Elements Present in All Transactions, 4 Hastings Bus. L.J. 315, 331 (2008) ("[F]ostering relationships with each other becomes just as important and fundamental to the contract as the transaction itself.").

41. See id.

42. To be sure, not all transactions are voluntary and there certainly are transactions where unequal bargaining power exists between the parties (e.g. hostile takeovers). Transactions, however, are typically voluntary exchanges between the parties. Of course power imbalance as between parties to an agreement or contract is another issue altogether. See Ian R. Macneil, The Many Futures of Contracts, 47 S. CAL. L. REv. 691, 715 (1974) [hereinafter Macneil, Futures] (arguing 
4. Attorneys Are at the Center of Litigation, While Clients Are the Center of Transaction.-Lastly, lawyers frequently dominate the litigation process. ${ }^{43}$ Although pro se litigation is theoretically possible, it is practically impossible in the world of impact litigation given the resources required to be successful. Instead, attorneys control the course of the litigation, especially in class impact suits, by making all of the decisions, including settlement decisions, with little or superficial input from clients. ${ }^{44}$ Moreover, before even bringing an impact litigation case, attorneys often strategically identify the right "sensitive social issue" and the right plaintiff or plaintiffs (i.e., those who will engender empathy or sympathy in court or from the public) to bring the "right test-case" to the exclusion of otherwise worthy clients. ${ }^{45}$

These power imbalances between lawyers and clients are largely absent in transactional practice. ${ }^{46}$ Impact litigation is largely initiated by lawyers seeking to effectuate social change through judicial remedies. In contrast, this Article presents impact transaction as initiated by clients seeking to effectuate social change through agreement. The deal-seeking involved in transactional work is a collaborative process with the clients at the center of the negotiation. ${ }^{47}$ "[Transactional lawyers] notion of justice tends to be related to whether the expectations of the parties themselves have been satisfied." ${ }^{48}$ As such, transactional law implicates a distinct value: "value produced from the outcome of the transaction for the parties." ${ }^{, 49}$

"status, social role, kinship" and other "internalizations" play a role in contract).

43. See, e.g., John Lande, Failing Faith in Litigation? A Survey of Business Lawyers' and Executives' Opinions, 3 Harv. NegOt. L. Rev. 1, 5 (1998) (describing how lawyers are the "primary players" in litigation).

44. For example, business "executives are often in the uneasy role of being formally responsible for making the major decisions while being pushed in a particular direction by the way the attorneys frame the choices. As a result, executives often just ratify decisions that the attorneys have already effectively made." $I d$. at 21.

45. See Gerald P. López, Rebellious Lawyering: One Chicano's Vision of Progressive Law Practice 14-17 (1st ed. 1992).

46. Power imbalances between lawyers and clients are not completely absent from transactional representation, and there is room in both transactional and litigation practice for client-centered lawyering. See, e.g., Alicia Alvarez \& Paul R. Tremblay, Introduction to Transactional LaWyering Practice (1st ed. 2013) (identifying approaches to client-centered lawyering).

47. See id.

48. Symposium, Relational Contracting in a Digital Age, 11 Tex. Wesleyan L. Rev. 675, 680 (2005).

49. Patience A. Crowder, Designing A Transactional Law Clinic for Life-Long Learning, 19 LEWIS \& Clark L. ReV. 413, 418 (2015). 


\section{B. Public Good Transactions and the Potential of Agreements to Accomplish Social Change}

Although courts facilitate impact litigation, transaction is facilitated by voluntary acts, including, for the subject of this Article, agreements. The value of agreement between parties is paramount, and agreement to address a particular social ill can promote the public good in ways that transcend impact litigation. In other words, it is time for impact transaction. ${ }^{50}$

"Contract" and "agreement" are not synonymous terms. In the law, "[a]n agreement is a manifestation of mutual assent on the part of two or more persons." ${ }^{, 51}$ A contract is a binding promise ${ }^{52}$ and contract "is legalese for the kinds of agreements courts enforce." ordering of preferences" ${ }^{\prime, 4}$ and parties to contracts are looking for predictability, risk allocation, and reliability from contracts. ${ }^{55}$ Contracts bring order to transactions by ordering and creating frameworks for transactional processes. Generally, there are five common elements in contracts across disciplines: (1) cooperation; (2) exchange; (3) mutual planning for the future; (4) potential sanctions; and (5) social control and social manipulation. ${ }^{56}$ Although those components of contract law have withstood centuries of legal analysis, contract law scholars vigorously debate whether new mechanisms are needed to "accommodate [the] new world of transactions." 57 This question extends beyond the creation of new products and technologies to encompass new strategic relationships and methods of service delivery. Today, contracts and agreements must serve important social and commercial functions with respect to maintaining social order and justice. ${ }^{58}$

50. See Praveen Kosuri, Impact in 3D: Maximizing Impact Through Transactional Clinics, 18 Clinical L. Rev. 1 (2011). In this article Praveen Kosuri lays the groundwork for the conceptualization of transactional law as an impact strategy using three distinct examples of client work from his experiences as a transactional law clinician. See generally id. Thus, for example, social change is advanced in a transactional law clinic when that clinic represents clients with social change missions. See id. at 40. That notion is certainly in accord with the premise of this Article. Moreover, this Article seeks to advance impact transaction as a strategy, in and of itself, for social change by scaling the concept of impact transaction up beyond discrete transactions to encompass the equivalent of a transactional class.

51. Restatement (SECOND) OF CONTRACts $\S 3$.

52. See id.

53. Martha M. Ertman, Love's Promises: How Informal and Formal Contracts Shape All Kinds of FAMILIES xii (Beacon Press 2015).

54. Larry A. DiMatteo \& Blake Morant, Contract in Context and Contract as Context, 45 WAKe Forest L. ReV. 549, 559 (2010).

55. Relational Contracting in a Digital Age, supra note 48, at 692.

56. See, e.g., Macneil, Futures, supra note 42, at 710-12 (discussing the role of the social matrix in contract).

57. Relational Contracting in a Digital Age, supra note 48, at 698.

58. Id. at 680 . 
Collective impact is not the first iteration of transaction for the public good. In fact, there is precedent for community-based contracts. Prior to the emergence of collective impact, those concerned with transactional efforts at social change could use documents such as memorandums of understanding (MOUs) and, more recently, community benefits agreements (CBAs). ${ }^{59}$ They could form social enterprises or engage in what is considered the most well-known space for transactions for the public good, community economic development (CED).$^{60} \mathrm{As}$ explained below, although each of these types of "public good transaction" provides tremendous services and relief to underserved communities, each also has certain limitations that inhibit impact transaction.

Although collaboration among social service providers is far from new, the earliest iterations of these arrangements, MOUs, are less encompassing in scope than collective impact agreements are intended to be. Historically, nonprofit organizations agreed to work together in principle for the benefit of obtaining support from funders to demonstrate in grant applications the breadth of their strategic partnerships. ${ }^{61}$ These arrangements are typically documented through nonbinding MOUs, which organizations use to document the existence of strategic partnerships in grant applications. ${ }^{62}$ MOUs are used by organizations to demonstrate their ability to work with other organizations to provide enhanced service delivery without duplicating services. ${ }^{63}$ Although seemingly an efficient way to fund and deliver nonprofit services, this ultimately created a culture in which nonprofit organizations, despite their strategic partnerships, are forced to compete against each other through grant applications for foundation and public charity dollars, perpetuating a zero sum game that promotes funded but isolated efforts at social change as opposed to facilitating broad social change. This funding structure has continued for generations as a hallmark of the funding of charitable organizations, providing limited opportunities for large-scale social change. In addition, because, as a practical matter, MOUs are generally aspirational in nature to set the expectations of the parties, these documents are

59. See, e.g., Sandy Gerber, Community Benefits Agreements: A Tool for More Equitable Development?, FED. RES. BANK MinNEAPOLIS (Nov. 1, 2007), https://minneapolisfed.org/ publications/community-dividend/community-benefits-agreements-a-tool-for-more-equitabledevelopment [https://perma.cc/DZB6-BPQ8].

60. See, e.g., Community Economic Development (CED), ADMIN. FOR CHILD. \& FAMILIES, http://www.acf.hhs.gov/programs/ocs/programs/ced [https://perma.cc/CJJ5-E9FM] (last visited Feb. 28, 2016).

61. Geri Stengel, Nonprofit Collaborations: Why Teaming Up Can Make Sense, ForBeS (Apr. 9, 2013, 10:02 AM), http://www.forbes.com/sites/geristengel/2013/04/09/nonprofitcollaborations-why-teaming-up-can-make-sense/\#7a47bc144c2c [https://perma.cc/S3FD-67YU] (noting "foundations are increasingly recognizing the value of [nonprofit organizations' collaboration] and are often willing to fund the process").

62. For an example, see Guidelines for a Memorandum of Understanding, DEP'T JUSTICE, www.doj.state.or.us/victims/pdf/mou_sample_guidelines.pdf[https://perma.cc/SAT7-H7PL](last visited Feb. 28, 2016).

63. See id. 
generally too vague and intentionally nonbinding, making them of little utility for advancing social change through impact transaction.

Social enterprises are for-profit businesses that pursue a primary corporate purpose of advancing the common good by using "the methods and disciplines of business and the power of the marketplace to advance their social, environmental, and human justice agendas. ${ }^{, 64}$ In other words, social enterprises are businesses that make profits both for the benefit of the owners' compensation as well as the advancement of a specific social purpose or mission. Well-known social enterprises include Tom's Shoes ${ }^{65}$ Light Gives Heat, ${ }^{66}$ and Sweet Beginnings. ${ }^{67}$ The pursuit of social change through social enterprise is growing in popularity in terms of both entrepreneurial start-ups and consumer awareness, meaning consumers are looking to support social enterprises with their dollars. Despite tremendous individual successes for targeted social causes, social enterprises are not well suited to create and sustain large-scale social change as impact transaction. This is because social enterprises do not typically act in concert with each other through networks, ${ }^{68}$ but independently in isolation, in joint pursuit of their social and business purposes. Although the totality of the social benefits attributed to social enterprises is impressive, social entrepreneurship, as currently structured and operating, is not structured to promote impact transaction.

Lastly, although not succinctly defined, notions of CED have shifted over the decades since the first CED projects in the 1960s. ${ }^{69}$ CED is both legal practice and social movement, and community participation lies at the heart of all CED efforts for community-based revitalization. ${ }^{70} \mathrm{CED}$ efforts have and continue to make remarkable transformations in neighborhoods throughout the country, and, until now, transactional advocacy in the public's interest largely occurred in the CED context. ${ }^{71}$

Although CED projects began for the purpose of increasing economic

64. What Is a Social Enterprise, BEAD FOR LIFE (Apr. 5, 2015), http://www.beadforlife.org/ blog/what-is-a-social-enterprise/ [https://perma.cc/L4RU-A75S]; see also Alicia E. Plerhoples, Representing Social Enterprise, 20 CliniCAL L. Rev. 215 (2013).

65. Toms, http://www.toms.com [perma.cc/FK66-EXEW] (last visited Feb. 28, 2016).

66. Light Gives HEAT, http://www.lgh.tv/\#welcome-1 [perma.cc/JBC5-ETBV] (last visited Feb. 28, 2016).

67. SweEt BeGINNINGS, http://www.sweetbeginningsllc.com [perma.cc/R8WW-C54T] (last visited Feb. 28, 2016).

68. This is not to suggest social enterprises are not connected to any networks. Organizations such as the Social Enterprise Alliance connect social enterprises and are a resource for their growth and development. See Soc. Enterprise Alliance, https://socialenterprise.us/ [https://perma.cc/4JHN-95U7] (last visited Feb. 28, 2016). These networks, however, do not seem to extend outward into society in a way that would support impact transaction.

69. See William H. Simon, The Community Economic Development Movement: Law, Business, AND the New Social Policy 4 (Duke Univ. Press 2001).

70. Id.

71. Crowder, supra note 28. 
opportunity in underserved communities, today's CED projects have strong market connections. ${ }^{72}$ This is particularly true for CED redevelopment efforts memorialized in community benefits agreements (CBAs). CBAs are private contracts between developers and community groups by which a community agrees to support a development project in exchange for certain benefits such as open green space, the construction of affordable housing, and first hiring preferences for community residents. ${ }^{73}$ The utility of CBAs as tools for largescale social change remains unsettled for the following two reasons. First, there are questions about the substance of the documents themselves, including the identification of the appropriate "community" to be governed by the CBA and questions about the document's ultimate enforceability. ${ }^{74}$ Second, as Scott Cummings argued, CED may be too localized in nature to address the large-scale social problems collective impact initiatives are designed to address, problems that span across metropolitan regions as opposed to neighborhoods. ${ }^{75}$

The benefits of public good transactions facilitated by MOUs between nonprofits, social enterprises, and CED are undeniable and, for many neighborhoods, transformative. The suggestion that these types of public good transactions inhibit this Article's idea of impact transaction is not an argument against their effectiveness or necessity. It is an acknowledgment social change has to happen on many fronts - at both the micro and macro levels. Poverty affects not just isolated communities but entire urban, suburban, and rural spaces. ${ }^{76}$ Given the broad geographic expanse of poverty, there is an urgent need for more expansive and comprehensive efforts at social change. As deal-making for the public good, collective impact is poised to facilitate that transformation as impact transaction.

\section{The Parameters of Impact Transaction}

With respect to social change there is a distinction between "equality" and "equity." Equality demands everyone participate in the same equal process, whereas equity demands everyone has access to the same opportunities and recognizes "access" must be a dynamic concept adaptable to meet different needs. ${ }^{77}$ Impact litigation is designed to pursue equality and impact transaction

72. See Scott L. Cummings, Community Economic Development as Progressive Politics: Toward a Grassroots Movement for Economic Justice, 54 STAN. L. REv. 399 (2001).

73. Julian Gross, Community Benefits Agreements: Definitions, Values, and Legal Enforceability, 17-WTR J. AfFordable Housing \& Community Dev. L. 35, 39 (Fall 2007/Winter 2008).

74. See Vicki Been, Community Benefits Agreements: A New Local Government Tool or Another Variation on the Exactions Theme?, 77 U. CHI. L. REV. 5 (2010).

75. Scott L. Cummings, Recentralization: Community Economic Development and the Case for Regionalism, 8 J. SMALl \& EMERGing Bus. L. 131, 144-45 (2004).

76. Elizabeth Kneebone \& Alan Berube, Confronting Suburban Poverty in AMERICA 2 (The Brookings Inst. 2013).

77. Vu Le, Why Equality Is Actively Harmful to Equity, NonProfit with Balls (Nov. 9, 
is designed to produce equity. ${ }^{78}$ Both, of course, are important.

Impact transaction is an alternative to impact litigation as a tool for largescale social change where a social justice outcome is predicated upon an infrastructure for implementation, high litigation costs, no individual rights at stake, and the client's role as more fundamental to the outcome rather than the lawyer's trial skills and litigation strategy. In addition, impact transaction seeks large-scale social change, where, once the strategy is more fully developed, possible outcomes could include agreements that achieve affordable regional housing development, equitable development of public transit throughout metropolitan regions, and increasing access to social venture capital for minority and women small business owners.

\section{COLLECTIVE IMPACT AS IMPACt TRANSACTION}

"Collective impact" is the name for a new social action strategy: "the commitment of a group of important actors from different sectors to a common agenda for solving a specific social problem," using a structured form of collaboration. ${ }^{79}$ As detailed below, collective impact has quickly evolved as a process and is gaining national attention..$^{80}$ The members of these initiatives can vary, and examples include a local neighborhood association, private business interests, and a governmental agency joining to clean up a local water source; a local government, chamber of commerce, and representatives from higher education and faith-based institutions collaborating to promote economic development throughout a metropolitan region; or a private foundation, local industry, and public school officials working together to improve the quality of and access to $\mathrm{K}-12$ educational opportunities in a Rust Belt city.

Ascribed as "an important framework for progress on social issues," terminology "collective impact" has a relatively short history. The term was first published in a 2011 Stanford Social Innovation Review article by John Kania and Mark Kramer, two philanthropic consultants who now specialize in collective impact training. ${ }^{82}$ Although the authors did not identify a new phenomenon, they put a label on existing behaviors and practices. This label normalized the concept

2015), http://nonprofitwithballs.com/2015/11/why-equality-is-actively-harmful-to-equity/ [perma.cc/F6FR-L86W]; see also Derrick A. Bell, Jr., Serving Two Masters: Integration Ideals and Client Interests in School Desegregation Litigation, 85 Y ALE L.J. 470, 507-09 (1976) (discussing the application of equity in the context of minority access to the judicial system).

78. See, e.g., IMPACT FUND, http://www.impactfund.org [https://perma.cc/P9KD-5SX3] (last visited Feb. 28, 2016) (describing The Impact Fund as an organization that "provide[s] strategic leadership and support for litigation to achieve economic and social justice").

79. John Kania \& Mark Kramer, Collective Impact in Collective InSIGHTS on Collective IMPACт 36, 36-41 (2014).

80. Id. at 36 .

81. James Capraro \& Joel Bookman, Building Sustainable Communities: Moving FROM QuALity of Life PlanNing to Implementation 10 n.1 (2014).

82. See Kania \& Kramer, supra note 79 , at 36. 
of collective impact and extended the roots of this framework into the territory of social movements. ${ }^{83}$

After the Stanford Social Innovation Review article in 2011, a series of events occurred that were milestones in the evolution of collective impact. Later in 2011, the Chronicle of Philanthropy dubbed "collective impact" as one of the philanthropy buzzwords of the year. "This term shows the power of a good buzzword to compel an idea. There's nothing new about government, nonprofits, the public, and commercial businesses working together. But the phrase 'collective impact' . . . helped focus attention and raise the idea to prominence again." ${ }^{, 84}$ In 2012, the White House Council for Community Solutions recognized the "the collective impact" framework as one of two designated strategies for advancing communities throughout the nation. ${ }^{85}$ Then, in 2013, FSG and the Aspen Institute Forum for Community Solutions formed the Collective Impact Forum. ${ }^{86}$ Launched in March 2014, the Collective Impact Forum is an online

83. Marketing theory explains branding concepts by name lends legitimacy to those products and services that are named. See Alex Frankel, Wordcraft: The Art of Turning Little Words INTO Big Business (Three Rivers Press 2005). Similarly, naming the collective impact framework made it an accessible framework capable of being more easily adopted, replicated, and implemented by multiple stakeholders and other interested parties. See id.

84. Lucy Bernholz, Philanthropy Buzzwords of 2011, Chron. Philanthropy (Dec. 27, 2011), https://philanthropy.com/article/Philanthropy-Buzzwords-of-2011/157395 [perma.cc/ZM45$\mathrm{S} 42 \mathrm{X}]$.

85. "The Council recognized that cross-sector community collaboratives, such as Strive, could represent an emerging national trend, where communities were working together to solve their biggest challenges." Michele Jolin et Al., NeEdle-Moving Community Collaboratives: A Promising Approach to Addressing AmericA's Biggest Challenges (2012), available at http://www.bridgespan.org/getmedia/7daleafe-f85a-4798-8774-7386058f2ce4/needle-movingcommunity-collaboratives-report.aspx [https://perma.cc/3324-KFJR].

On December 14, 2010, President Obama signed an executive order establishing the White House Council for Community Solutions to engage a diverse group of prominent cross-sector leaders to:

(i) Connect, convene and catalyze the best resources of the public, private, non-profit and philanthropic sectors in communities across the country

(ii) Identify and highlight solutions that work

(iii) Identify key attributes of effective cross-sector solutions from institutions working together on community problems

(iv) Catalyze resources to support effective community-based solutions.

On June 4, 2012, the Council delivered its Final Report and Recommendations to President Obama.

White House Council for Community Services, UnITEd We SERvE, http://www.sferve. gov/?q=site-page/white-house-council-community-services [perma.cc/K46A-U8J] (last visited Feb. 28, 2016).

86. Collective Impact Forum, FSG, http://www.fsg.org/collective-impact-forum [perma.cc/ 
clearinghouse for collective impact practitioners, funders, consultants, and backbone agencies with over ten thousand members. ${ }^{87}$ Today, there are collective impact initiatives underway in each of the twenty-five largest cities in the United States. $^{88}$

Given the pace of collective impact's development, it is important to understand what collective impact is and what it is not. This Part presents the collective impact framework, including descriptions of the earliest documented collective impact projects and an analysis of the unquantifiable value and inherent risks in collective impact.

\section{A. Collective Impact Defined}

An internet search of "collective impact" will yield a diverse collection of articles and blog posts about the collective impact framework, projects, and a list of consultants and experts who specialize in advising organizations and local governments about the structure and implementation of collective impact initiatives. Collective impact is generally defined as a "[c]ommitment of a group of important actors from different sectors to a common agenda for solving a specific social problem," using a structured form of collaboration. ${ }^{89}$ As detailed below, the defining feature of the collective impact framework is its structured infrastructure.

Collective impact proponents urge, "[c]ollective impact is not just a new term for collaboration [but] it represents a fundamentally different, more disciplined, and higher-performing approach to achieving large-scale impact." $"$ The collective impact framework encourages the adoption of the "broad view" of social issues and forces participants to work towards a common goal, which prevents the parties from operating as siloes. Therefore, collective impact is not merely a dressed-up form of agency collaboration. ${ }^{91}$ Significantly, collective impact networks differ from other types of partnerships and cooperative ventures because collective impact networks "involve[] a centralized infrastructure, dedicated staff, and structured process." interdependence among the members of a collective impact network, encouraging members to alter their own organizational behavior to create solutions to the

45PD-WLRB] (last visited Feb. 28, 2016).

87. COLLECTIVE IMPACT F., http://collectiveimpactforum.org/ [perma.cc/D4HZ-XET9] (last visited Feb. 28, 2016).

88. Empirical data on file with the author.

89. Kania \& Kramer, supra note 79, at 36-41.

90. Collective Impact, MEMPHIS FAST FORWARD, http://memphisfastforward.com/ collectiveimpact [perma.cc/5KGA-D2Z3] (last visited Feb. 28, 2016).

91. Collective impact "[d]oes not simply imply more partnerships or collaborations ... [it] moves beyond traditional modes of partnership and collaboration." Bixby, supra note 7, at 1 .

92. Kania \& Kramer, supra note 79, at 38. See infra Part IV for discussion on legal distinctions between collaborative structures. 
targeted social problem. ${ }^{93}$ Then, theoretically, each member must meaningfully contribute to conclude a collective impact initiative successfully.

Collective impact is a more sophisticated form of collaboration. ${ }^{94}$ Collaborations are formed to achieve specific outcomes through predetermined actions and assignments. ${ }^{95}$ However, collective impact initiatives target social problems but do not predetermine specific approaches to solve those problems. ${ }^{96}$ Instead, fundamental to the collective impact infrastructure is the creation of a process that will determine these outcomes. ${ }^{97}$

This infrastructure is built around the following five characteristics: (1) a common agenda; (2) shared measurement; (3) mutually reinforcing activities; (4) continuous communication among the parties; (5) and the implementation of backbone support organizations. ${ }^{98}$

First, parties to collective impact initiatives agree on a common agenda. ${ }^{99}$ To be successful, collective impact initiatives require "all participants to have a shared vision for change, one that includes a common understanding of the problem and a joint approach to solving it through agreed upon actions." ${ }^{100}$ Second, there must be an understanding of shared measurement in order to engineer data collection that complements the common agenda and speaks to

93. Collective impact initiatives, to a certain extent, are a "great equalizer" because all of the parties have to approach learning about each other and their industries to enhance trust in the relationship and, ultimately, to lead to changed behavior. For example, in the evolution of the StrivePartnership collective impact, the participating business leaders had to a learn to appreciate "the distinct differences in addressing problems in the private sector compared to the more complex social sector" and "once they embraced and accepted that complexity, the business leaders learned to work within a collective impact approach rather than on standalone efforts." Allen Grossman et al., StriveTogether: Reinventing the Local Education Ecosystem, 2014 HARV. Bus. SCH. 1, 4, available at http://www.hbs.edu/faculty/Pages/item.aspx?num=45833 [https://perma.cc/9QS7GM2Y].

The problem with relying on the isolated impact of individual organizations is further compounded by the isolation of the nonprofit sector. Social problems arise from the interplay of governmental and commercial activities, not only from the behavior of social sector organizations. As a result, complex problems can be solved only by crosssector coalitions that engage those outside the nonprofit sector.

Kania \& Kramer, supra note 79 , at 39.

94. Steve Wright, The Tactics of Collaboration, Stan. Soc. InNOVATION ReV. (Nov. 4, 2014), http://ssir.org/articles/entry/the_tactics_of_collaboration [perma.cc/2HAJ-7VVD].

95. See generally id.

96. See generally Saphira M. Baker \& Kelly King Horne, Second-Generation Collective Impact, StAn. Soc. InNOvATION Rev. (Feb. 16, 2016), http://ssir.org/articles/entry/second generation_collective_impact [https://perma.cc/TD8A-WFPD] (discussing the process through which one collective impact initiative was successful).

97. See generally id.

98. Kania \& Kramer, supra note 79, at 39-40.

99. Id. at 39 .

100. Id. 
agreement around "the ways success will be measured and reported" to ensure that individual efforts of each member of the initiative remain aligned and that, ideally, participants can hold each other accountable while learning from each other's successes and failures. ${ }^{101}$ Third, parties to collective impact initiatives must engage in mutually reinforcing activities whereby each participant is encouraged to undertake its specific skill set to support and complement the activities of the other participants for the benefit of the initiative's overall goal. ${ }^{102}$ Fourth, parties to collective impact must engage in continuous communication, including creating a common vocabulary within collective impact initiatives, which is an essential prerequisite to developing shared measurement systems, and requiring high-level representatives to meet regularly to work to advance the initiative. ${ }^{103}$ Lastly, backbone support organizations, or "backbone agencies" as discussed in detail below, are an essential component of any collective impact initiative; they are separate organizations staffed with skilled individuals who can fill the role of project manager, data manager, or facilitator. ${ }^{104}$

These five conditions for success provide the foundation for each collective impact initiative. The common agenda attracts participants to a given collective impact initiative. ${ }^{105}$ Shared measurement for data collection and mutually reinforcing activities promote interdependence among the participants to advance the initiative outcome. ${ }^{106}$ Continuous communication reinforces levels of trust among the participants. ${ }^{107}$ Finally, the backbone agency works to ensure the other four conditions are being advanced within an initiative by serving as a project manager extraordinaire. ${ }^{108}$ The specific context of each individual initiative will, of course, be tailored to each initiative's focus on social change. However, this framework provides structure above and beyond common collaboration and is what sets collective impact apart. These five conditions for success are to be the foundation of any given collective impact initiative, regardless of whether there is an accompanying collective impact agreement.

\section{B. Standard Parties to Collective Impact Initiatives}

An important characteristic of collective impact initiatives is the diverse range of parties that typically comprise collective impact networks: (1) one or more backbone agencies; (2) non-backbone initiative members; (3) one or more funders to provide technical or financial support; (4) and a collective impact consultant. ${ }^{109}$ These parties are a mix of nonprofit organizations, public entities

101. Id. at 40 .

102. Id.

103. Id.

104. Id.

105. See id. at 39.

106. See id. at $40-41$.

107. Id.

108. Id. at 40 .

109. See generally What is Collective Impact, Collective ImPACt F., http://collective 
(including state and local governments), educational institutions, the private sector, and representatives of the targeted community. ${ }^{110}$

1. Backbone Agencies.-Backbone agencies are essential to the success of collective impact initiatives. These agencies are independent entities with their own dedicated staff and physical space. ${ }^{111}$ In many respects, the backbone agency is a project manager for the collective impact initiative. ${ }^{112}$ Backbone agencies must work with the other organizations in a given collective impact network to "build consensus around a common goal, agree on how progress will be measured, and coordinate activities to maximize results." $" 113$

Backbone agencies do not provide any services directly related to the program delivery. ${ }^{114}$ Instead, backbone agencies focus "on the relationships between organizations and the progress toward shared objectives." 115 Backbone agencies coordinate the activities of the other stakeholders in the collective impact network. ${ }^{116}$ Moreover, backbone agency duties extend beyond that of management and agenda setting to facilitate the initiative's remaining four characteristics common agenda, shared measurement, activities, and communication. ${ }^{117}$ Backbone agencies must work with the other members of a collective impact network by fostering changed behavior and attitudes, which can be difficult because backbone agencies do not have any inherent authority over the other participants. ${ }^{118}$ "As a result [they] must build [their] own authority to exert influence." 119 Over the lifecycle of a collective impact initiative, backbone agencies perform the following general and specific functions: ${ }^{120}$

impactforum.org/what-collective-impact [https://perma.cc/ENQ5-EZN3] (last visited Feb. 28, 2016).

110. See Kania \& Kramer, supra note 79, at 40; see also infra notes $195-99$ and accompanying text for a discussion about the risks related to the lack of community involvement.

111. Kania \& Kramer, supra note 79, at 40.

112. See, e.g., Request for Proposals Issued for a Backbone Organization, Collective IMPACT F.(Sept. 12, 2012, 7:20pm), https://collectiveimpactforum.org/resources/request-proposalsbackbone-organization [https://perma.cc/STD6-2MV4] [hereinafter Request for Proposals]. Also, this role can be performed by a single organization, connected individuals, or a shared service model across organizations.

113. Bixby, supra note 7, at 12 (discussing research by Turner, Errecart, and Bhatt analyzing backbone agency behavior).

114. Kania \& Kramer, supra note 79 , at 40.

115. Id. at 39 .

116. Id. at 40 .

117. Id.

118. Bixby, supra note 7 , at 2 .

119. Id.

120. Shiloh Turner et al., Understanding the Value of Backbone Organizations in Collective Impact: Part 1, Stan. Soc. InNOvation Rev. (July 17, 2012), http://ssir.org/articles/entry/ understanding_the_value_of_backbone_organizations_in_collective_impact_1 [perma.cc/9VFVR29M]; see also Networks for Collective Impact, RURAL SUPPORT PARTNERS, http://www.rural supportpartners.com/networks-for-collective-impact.php [perma.cc/WJE8-6JGR ] (last visited Sept. 


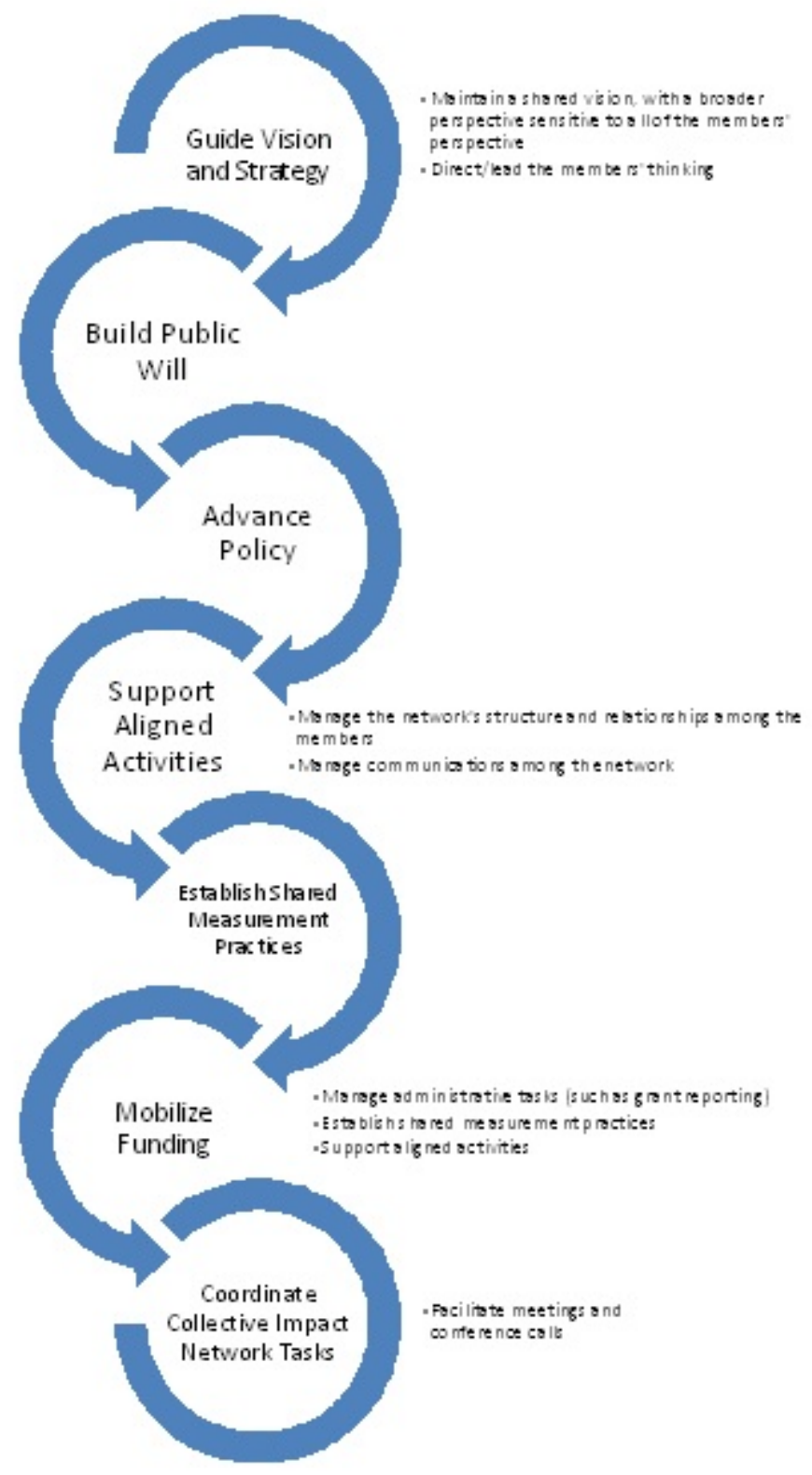

The number one reason collective impact initiatives fail is ineffective $\mathrm{e}^{121}$

13, 2015).

121. Effective backbone agencies are visionary, results-oriented, collaborative-relationship builders, focused on the common agenda but able to adapt, charismatic and influential, politic, and humble. Networks for Collective Impact, supra note 120. The backbone agency is a new role and, 
backbone support. ${ }^{122}$ This role comes with certain challenges. ${ }^{123}$ First, there is an ongoing potential for background agencies to be pulled into too many directions while managing a collective impact initiative. Second, backbone agencies need sufficient resources to tackle the substantial work required to recruit new organizations into collective impact initiatives. Third, backbone agencies need to have long-range vision because collective impact occurs at a very measured pace. Fourth, the substantive capacity of the backbone's expertise must be deep and wide on the relevant issues. Lastly, collective impact parties must be aware of the potential structural limitations on a backbone agency. For example, the geographic reach and scope of the collective impact initiative may not match the backbone agency's strengths.

2. Collective Impact Participants.-Participants in collective impact initiatives seek to build an infrastructure to provide a comprehensive focus on a particular social ill. This requires a diverse group of participants in any given initiative. ${ }^{124}$ Organizational participants of collective impacts range in size and purpose; typically, participants include universities, nonprofit organizations with a range of missions, government agencies, and business interests. ${ }^{125}$ These members provide "specialized assistance and resources specific to their ability" with the goal of avoiding unnecessary duplication in agency types and skill sets within a collective impact network. ${ }^{126}$ To demonstrate a serious commitment to participate in collective impact initiatives, representatives of the network members should include CEO-level leadership of each participant such as university presidents, school district superintendents, and business, nonprofit, and government leaders.

a. Funders and other supporters of collective impact.-Collective impact initiatives benefit from monetary and nonmonetary support. Participating in

arguably, profession and expertise in social justice advocacy and philanthropy.

122. Given the significance of the backbone agency, it is particularly important to set up procedures for assessing a backbone's performance. First, according to survey responses, the value of backbone agencies is unmistakable. Second, backbone agencies must exhibit strength to guide a collective impact initiative's vision and strategy and support aligned activities. Third, backbone agencies must be fluid enough to shift a collective impact initiative's focus over time. Fourth, a primary function of backbone agencies is to provide ongoing assistance with data generation and collection. Lastly, backbone agencies help build public will and advance policy concerning collective impact initiatives. Shiloh Turner et al., Understanding the Value of Backbone Organizations in Collective Impact: Part 3, Stan. Soc. InNOvation Rev. (July 19, 2012), $\mathrm{http}$ ///ssir.org/articles/entry/understanding_the_value_of_backbone_organizations_in_collective _impact_3 [perma.cc/DV75-8UBC].

123. Id.

124. Collective Impact Model, 5 Marketwise Community 1, 5 (2015), available at https://www.richmondfed.org/publications/community_development/marketwise_community/2 015/issue_1/mwc_vol5-issue1_p3_collective_impact [perma.cc/FQM2-HC4B] (last visited Feb. 28, 2016).

125. Kania \& Kramer, supra note 79 , at 40.

126. See Collective Impact Model, supra note 124, at 5. 
collective impact initiatives requires significant time and financial commitment from backbone agencies and participants. ${ }^{127}$ Consequently, funders-including private foundations, public charities, and business enterprises-play three significant roles in collective impact initiatives. First, funders support the initiative's infrastructure. ${ }^{128}$ Second, funders have an advisory role where they create processes to educate collective impact organizations about particular social issues and facilitate the organizations' problem-solving around the social issue. ${ }^{129}$ Third, funders provide technical support and expertise on projects such as data collection, professional development, and skills directly related to the scope of the initiative. ${ }^{130}$

In addition to the monetary, advisory, and operational support provided by funders, collective impact initiatives also receive significant nonmonetary support from public institutions. Federal Reserve banks provide a very interesting example. ${ }^{131}$ The Federal Reserve banking system is responsible for conducting economic research, collecting data, and publishing reports about that research. ${ }^{132}$ To date, four of the twelve Federal Reserve banks have supported collective impact initiatives - namely the San Francisco, Cleveland, Richmond, and Atlanta Federal Reserve banks. ${ }^{133}$ These Federal Reserve banks do not give money to collective impact initiatives. Instead, the banks support and facilitate data collection, such as poverty metrics, in collective impact initiatives in accordance with the general purpose of the Federal Reserve banks. ${ }^{134}$ Although this support is significant, these Federal Reserve banks have also provided financial and economic development expertise to help operationalize the data. This function is particularly important to collective impact initiatives focused on economic development issues.

b. Consultants and experts. - The birth of collective impact initiatives as a

127. See generally Eric Nee \& Michele Jolin, $Q \& A$ Roundtable on Collective Impact, 2012 Stan. Soc. InNOVATION Rev. 24, available at http://ssir.org/articles/entry/roundtable on_collective_impact [https://perma.cc/Z4AA-5J62].

128. Id. at 28 .

129. See generally id.

130. See generally id.

131. See, e.g., The Power of Collective Impact, Fed. Res. BAnK Atlanta, https://frbatlanta. org/commdev/publications/partnersupdate/2014/03/14no3_collective_impact.aspx [https://perma.cc/MPR2-QKFL] (last visited Feb. 28, 2016).

132. In addition, the Federal Reserve banking system is responsible for supervising and regulating banks, maintaining the stability of the financial system, and providing financial services to depository institutions, the U.S. government, and foreign official institutions. See Current FAQs: Informing the Public About the Federal Reserve, FED. RES, http://www.federalreserve.gov/faqs/ about_12594.htm [perma.cc/Q48T-XERM ] (last visited Feb. 28, 2016).

133. The Richmond, Cleveland, and Atlanta Federal Reserve banks have partnered with a number of organizations to support small businesses and entrepreneurs in Appalachia. See Collective Impact Model, supra note 124, at 7.

134. See id. 
strategy for social change has fostered the creation of a new consulting niche. ${ }^{135}$ Collective impact consulting is quickly becoming a specialty as consultants design, launch, and monitor collective impact initiatives. ${ }^{136}$ Although they are not backbone agencies or funders, these consultants work closely with backbone agencies to facilitate strategic decision-making within a collective impact initiative. Moreover, even before an initiative commences, a consultant may be responsible for issuing a request for proposals (RFP) for development of backbone infrastructure. ${ }^{137}$

Already, there are several prominent collective impact consultants working with local, national, and international initiatives. ${ }^{138}$ The Spark Policy Institute is

135. As explained earlier in Part II, the role of the backbone agency is developing into both a new social justice profession. See supra Part II.B.1. Backbone agencies are already utilizing "a methodology used to improve business processes by utilizing statistical analysis rather than guesswork," which is frequently a preferred training for collective impact facilitators. Operational Excellence, 6Sigma (Sept. 13, 2015), http://www.6sigma.us/lean-six-sigma-trainingcertifications/operational-excellence [http://perma.cc/ABK5-SGA8].

136. See, e.g., SPARK POL'y InSt., http://www.sparkpolicy.com/about.htm [http://perma. cc/8JP8-9PZB] (last visited Feb. 28, 2016).

137. RFPs may seek information including why the organization wants to serve as the backbone, what expertise the organization has, how the organization will act as a neutral convener, and what staff or infrastructure the organization has available. See, e.g., Request for Proposals, supra note 112 .

138. Other collective impact consultants include:

(1) Civic Canopy: Working at the local level in Denver, Colorado, the "Civic Canopy is an inclusive network of partners working together to build stronger neighborhoods, healthier communities, and a more civil society ... The Civic Canopy designs innovative tools and facilitates collaborative processes that create the conditions for meaningful change." The Civic Canopy, ColoradoGives.org, https://www.coloradogives.org/CivicCanopy/ overview [https://perma.cc/ZJ2B-L6YW] (last visited Feb. 28, 2016).

(2) FSG: FSG is a consulting firm with a global reach that focuses on supporting leaders in creating "large-scale, lasting social change." About, FSG, http://www.fsg.org/about [https://perma.cc/4Z8R-K4EL] (last visited Feb. 28, 2016). Through strategy, evaluation, and research, FSG helps many types of actors-individually and collectively- "accelerate progress" against the world's toughest problems. Id. John Kania and Mark Kramer, authors of the Stanford article cited so prevalently herein, work for FSG; Kania is a managing director, and Kramer is the co-founder as well as a managing director. Our People, FSG, http://www.fsg.org/our-people [https://perma. cc/WPU5-JBXQ] (last visited Feb. 28, 2016).

(3) Collective Impact Forum: The Aspen Forum for Community Solutions partnered with FSG in 2014 to launch the Collective Impact Forum, which continues to provide the research findings of the two groups, as well as provide an online community to help support the efforts of those across the country using the collective impact method. Collective Impact Forum, supra 
one example of a national collective impact consultant partnering with communities, policymakers, advocates, and the general public to find solutions that bridge sectors, policy issues, levels of government, and diverse beliefs and values. ${ }^{139}$ Spark's services include systems building, community engagement, and complex project management. ${ }^{140}$

note 86 . The Collective Impact Forum appears to be at the cutting edge of collective impact practice and provides current updates for live projects, as well as news releases. Id.

(4) Tamarack Institute: Founded in 2001, the Tamarack Institute is an international charity "that develops and supports learning communities that help people to collaborate, co-generate knowledge and achieve collective impact on complex community issues." TAMARACK INST., http://tamarackcommunity.ca/ [http://perma.cc/YJ6V-Q9AM] (last visited Feb. 28, 2016). It sponsors three "learning communities" that function as informational outlets for their respective topics. Id. Demonstrating the growing popularity of collective impact, the Tamarack Institute held a collective impact conference in September and October 2015 to provide training and professional development to collective impact practitioners and those interested in learning more about collective impact. Collective Impact Summit, TAMARACK INST., http://events.tamarackcommunity.org/collective impactsummit [https://perma.cc/4QHM-LJRP ] (last visited Feb. 26, 2016).

(5) The Bridgespan Group: The Bridgespan Group is an organization that facilitates the use of collective impact through its informational blogs, financial consultation, information sharing on community collaborations, and tools which streamline the process of hiring nonprofit leaders. See generally BRIDGESPAN GROUP, http://www.bridgespan.org/ [http://perma.cc/5ZDTUTUW] (last visited Feb. 28, 2016). Specifically, the Bridgespan Group has worked with the White House Council for Community Solutions on its efforts at collective impact and has identified twelve successful collaborations, including the Milwaukee Teen Pregnancy Initiative, Philadelphia's Project Uturn, and Strive. Needle-Moving Collective Impact Guide: Capacity and Structure, BRIDGESPAN GROUP, http://www.bridgespan.org/Publications-andTools/Revitalizing-Communities/Community-Collaboratives/Guide-Capacityand-Structure.aspx\#.VtOOvJwrLIU [https://perma.cc/QGB3-JSHZ] (last visited Feb. 28, 2016).

139. SPARK POL'y InST., supra note 136.

140. Id. 


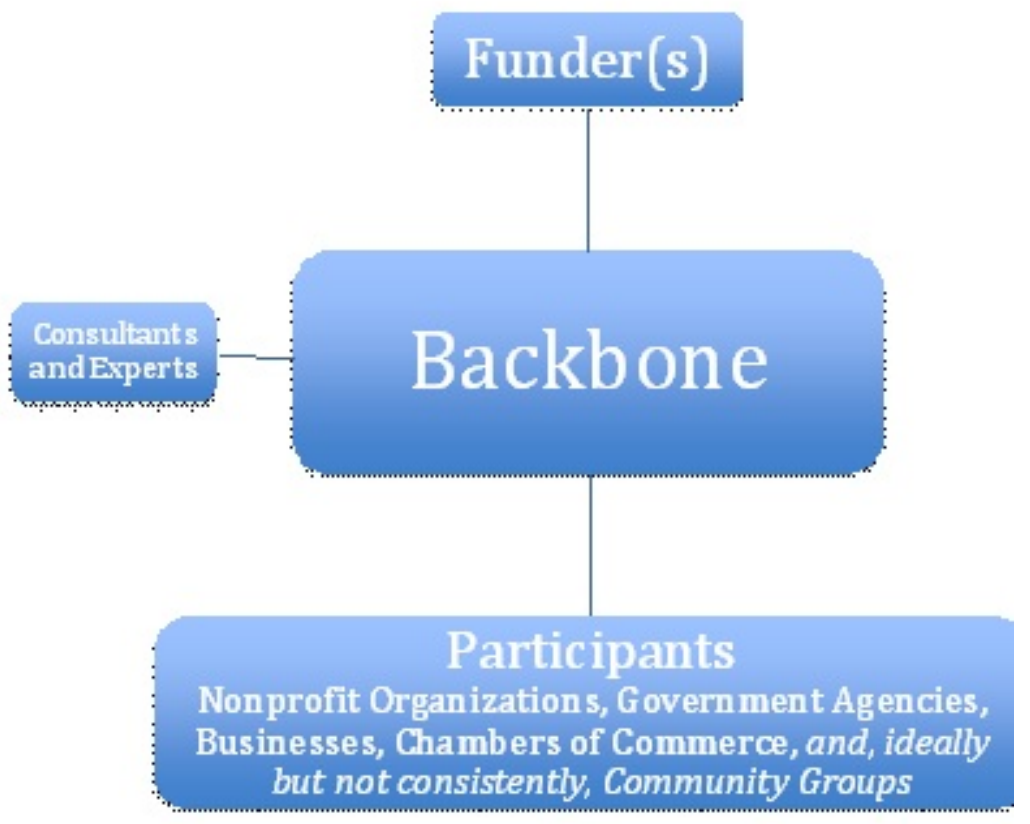

3. Examples of Diverse, Successful Collective Impact Initiatives.-Collective impact initiatives appear well-suited to mobilize around any type of social problem. To date, collective impact initiatives have generally fallen into one of the following categories: youth development; educational reform; environmental protection; health and welfare; and economic development. What follows is a brief description of some of the more established collective impact initiatives.

In the education sector, StriveTogether is a "cradle to career" collective impact initiative focused on education reform. ${ }^{141}$ It is widely recognized as one of the most successful collective impact initiatives to date and is an example of how a well-funded collective impact initiative can become a national, replicable model for social change. ${ }^{142}$ StriveTogether "has brought together local leaders to tackle the student achievement crisis and improve education throughout greater Cincinnati and northern Kentucky."143 This initiative represents sixty-one community partnerships in thirty-one states involving more than 9,000 organizations. ${ }^{144}$ StriveTogether's annual budget is $\$ 1.5$ million; however, when

141. StriveTogether, http://www.strivetogether.org/ [https://perma.cc/E8EE-2VHY] (last visited Feb. 28, 2016).

142. Kania \& Kramer, supra note 79, at 36-38.

143. Id. at 36 .

144. Stanford (California), Indianapolis, Houston, Richmond (Virginia), and Hayward (California) are the first four communities to implement Strive's process for education reform. Id. 
considering the efforts and increasing the effectiveness of organizations in its collective impact initiative, the combined budget is $\$ 7$ billion. ${ }^{145}$

The Elizabeth River Project is one of the earliest identified collective impact initiatives. ${ }^{146}$ The initiative was founded in 1991 with the mission to clean up the Elizabeth River located in Portsmouth, Virginia. ${ }^{147}$ The river was long used as a dump for industrial waste. ${ }^{148}$ Still active today through working groups and an extensive governance model, the Elizabeth River Project has more than 100 stakeholders, including representatives from government, science, business, and citizen interests, who compiled recommendations as to the most effective, affordable, and acceptable solutions to the problems of the Elizabeth River. ${ }^{149}$

Shape Up Somerville is a collective impact initiative comprehensively planned to advance food justice in Somerville, Massachusetts; its goal is to combat childhood obesity in elementary school children. ${ }^{150}$ This collective impact initiative is notew orthy for its diversity of organizational members and its narrow focus. ${ }^{151}$ With Shape Up Somerville acting as the backbone support organization, this initiative works to bring community partners together in a structured manner to achieve social change by providing opportunities for improved health and fitness outcomes to elementary school children. ${ }^{152}$ Shape Up Somerville works with restaurants across the city to enhance food options for people and families

at 41 n.3. Portland (Oregon), Fresno (California), Mesa (Arizona,), Albuquerque, and Memphis are just beginning their efforts. Id. "As learning accumulates Strive staff will incorporate new findings into an Internet-based knowledge portal that will be available to any community wishing to create a collective impact initiative based on Strive's model." Id. at 41. For StriveTogether's Data Sharing Playbook, see Data Drives School-Community Collaboration: Seven Principles for Effective Data Sharing, COMMUNITY IMPACT REP.CARD, http://circ.communityreport.org/data-sharing-playbook/ reports/73/data-drives-school-community-collaboration [https://perma.cc/98RY-24Z5] (last visited Feb. 28, 2016).

145. Id. at 41 .

146. ElizABeth River Project, http://www.elizabethriver.org/ [http://perma.cc/LW5QRZ6P] (last visited Apr. 4, 2016).

147. Explore the Elizabeth's Lauded Past, ElizABeth River Project, http://www.elizabethriver.org/\#!history/cyc5 [http://perma.cc/34NQ-QJTA] (last visited Feb. 28, 2016).

148. Id.

149. Watershed Action Plan, Elizabeth River Project, http://www.elizabethriver.org/ \#!watershed-action-plan/c118m [http://perma.cc/3FM8-CVWY] (last visited Feb. 28, 2016).

150. Shape up Somerville, SOMERVILlE, MASS., http:/www.somervillema.gov/departments/ health/sus [http://perma.cc/7ZG2-9B4L] (last visited Feb. 28, 2016).

151. Id.

152. Id. 
who eat out. ${ }^{153}$ In 2005, twenty-one restaurants were "Shape Up Approved." ${ }^{154}$ To receive this approval, Shape Up Somerville required restaurants to offer low fat dairy products, offer some dishes in a smaller portion size, offer fruits and vegetables as side dishes, and have visible signs that highlight the healthier options. $^{155}$

Memphis Fast Forward is an economic development collective impact initiative. ${ }^{156}$ This initiative was created from the collaborative efforts of the mayors from Memphis and Shelby County and an entity called Memphis Tomorrow. ${ }^{157}$ Memphis Fast Forward is a collective impact initiative that seeks to facilitate community development in areas including job creation, public safety, government efficiency, and producing a better-educated workforce. ${ }^{158} \mathrm{It}$ has an impressive scope of success and a comprehensive set of goals for social change, including a focus on economic development. ${ }^{159}$ In its first five years, the group boasted a $22.8 \%$ decrease in violent crime, a $25.5 \%$ decrease in property crime, the adoption of new anti-blight laws, ${ }^{160}$ and the generation of new minority business receipts of $\$ 576$ million, and new capital investment of more than $\$ 4$ billion. ${ }^{161}$

\section{The Unquantifiable Value and Manageable Risks of Collective Impact}

As a strategy for social change, collective impact houses an unquantifiable and unique value yet to be fully realized. Collective impact's value comes from both the work the individual initiatives perform and the impact the process itself has in the philanthropic community. ${ }^{162}$ As collective impact initiatives are

153. Christina D. Economos et al., A Community-Based Restaurant Initiative to Increase Availability of Healthy Menu Options in Somerville, Massachusetts: Shape Up Somerville, Preventing Chronic Disease, July 2009, at 5, available at http://www.cdc.gov/pcd/ issues/2009/jul/pdf/08_0165.pdf [https://perma.cc/FXM4-XWV5].

154. Id.

155. Id. at 4 .

156. Collective Impact: Silver Buckshot Versus Silver Bullet, MEMPHIS FAST FORWARD, http://memphisfastforward.com/collectiveimpact [http://perma.cc/5KGA-D2Z3] (last visited Feb. 28, 2016).

157. Org Chart, MEMPHIS FAST FORWARD, http://memphisfastforward.com/orgchart [http://perma.cc/5KGA-D2Z3] (last visited Feb. 28, 2016).

158. Id.

159. Id.

160. Operation Safe Community, MEMPHIS FAST FORWARD, http://memphisfast forward.com/publicsafety [https://perma.cc/N9WS-CVZL] (last visited Feb. 28, 2016).

161. Edging Forward in Economic Planning, MEMPHIS FAST FORWARD, http://memphis fastforward.com/edging-forward-in-economic-planning [https://perma.cc/3S3L-TL6D] (last visited Feb. 28, 2016).

162. See generally Marcie Parkhurst \& Hallie Preskill, Learning in Action: Evaluating Collective Impact in Collective Insights on Collective ImPACt 17 (2014), available at http://ssir.org/articles/entry/learning_in_action_evaluating_collective_impact 
established with increasing frequency across the country, advocates will continue to discover new benefits to the collective impact framework. Yet, with any new process comes certain risks. The risks most inherent in collective impact frameworks, however, can be managed and, in fact, would be best managed by a written agreement.

1. Paradigm Shifts.-Although most benefits are associated with the novelty of the structured framework and the resulting positive social outcomes, an important but unquantifiable value of collective impact is the significant paradigm shifts collective impact is igniting in the philanthropic and social services realms. Collective impact reflects an evolution in advocating for social change. It is changing the way local governments and nonprofits collaborate to accomplish the delivery of social and public services. It is engendering paradigm shifts in the funding practices of private foundations. It is expanding the breadth of social justice philanthropy through the creation of new professional roles and functions. Finally, it is fostering a new role for the private sector and business interests in economic development-as funders directly support economic development efforts instead of merely benefitting from a government's economic development incentives. A few of these paradigm shifts are discussed below.

a. Moving beyond isolated impact and technical problems to identify and embrace adaptive Problems in Social Service Delivery.-A paradigm shift engendered by collective impact affects the delivery of social services. Specifically, it is a shift in focus from targeting technical social problems to targeting adaptive social problems. ${ }^{163}$ This shift encourages collective impact initiatives to avoid making isolated impacts in social problems, the traditional form of social service intervention. ${ }^{164}$ Instead, this shift engages in more largescale interventions. ${ }^{165}$

The traditional way of funding singular nonprofit organizations and their particular programs promotes isolated interventions and limited engagements with social issues. ${ }^{166}$ "By their very nature, individual nonprofit services are fragmented and dispersed, with each organization typically serving a limited population with specific interventions." ${ }^{167}$ Funders then measure success at the organizational level, ignoring the broader community. ${ }^{168}$ Unfortunately, those measures then reflect a lack of success in broader social change that frustrates invested parties, such as taxpayers, funders, policymakers, service providers, and community members. ${ }^{169}$

[http://perma.cc/X7L3-3XK6].

163. See generally John Kania et al., Essential Mindset Shifts for Collective Impact in Collective Insights on COllective ImPACt 2 (2014), available at http://ssir.org/ articles/entry/essential_mindset_shifts_for_collective_impact [http://perma.cc/VUV8-88ZB].

164. Id.

165. Id.

166. Id.

167. JOLIN ET AL., supra note 85.

168. Id.

169. Id. 
Although isolated impacts on social problems certainly provide undeniable benefits to individual recipients, these limited encounters inhibit broader community-wide development. In contrast, collective impact is designed to engineer large-scale social change as opposed to making isolated interventions on social problems. ${ }^{170}$

As collective impact initiatives focus on adaptive social problems, ${ }^{171}$ advocates have acknowledged that collective impact is not a suitable strategy for all social problems because it is specifically designed to address adaptive problems instead of technical ones. ${ }^{172}$ Adaptive problems are complex problems with unknown or yet to be discovered answers and, even if an answer is identified, for which no single entity "has the resources or authority to bring about the necessary change." 173 Poverty, for example, is an adaptive problem because, despite centuries of effort, there is no singular quantifiable "fix" or "cure" for poverty. ${ }^{174}$ Poverty has proven not to be a social problem a single organization can manage. Technical social problems, in contrast, are well defined and able to be addressed by one organization. A food bank providing free food or prepared meals to the chronically homeless who reside in a particular public park is a demonstration of managing a technical problem - those who are hungry in the park. Technical social problems are single-dimensional, causing them to be ill suited for collective impact initiatives. Collective impact is, instead, designed for multidimensional problem solving, where there is a breadth of issues and the different perspectives on those issues held by a diverse group of stakeholders. ${ }^{175}$ Collective impact is evolving to tackle problems other techniques aimed at social change have failed to resolve.

b. Changing funder norms and funding practices.-Another paradigm shift engendered by collective impact relates to funder norms and funding practices. For generations funders have adhered to funding practices that awarded grants to individual organizations where the funds were limited to a specific charitable program, resulting in an isolated intervention on social problems. ${ }^{176}$ Funders of collective impact initiatives, however, are not solely focused on only funding specific programs, but are increasingly willing to fund a grantee's operational and planning needs. ${ }^{177}$

170. See generally Kania et al., supra note 163 .

171. $I d$.

172. Id.

173. Kania \& Kramer, supra note 79 , at 39.

174. Practitioner Insights: Federal Reserve Bank of San Francisco, Collective IMPACt F., http://www.collectiveimpactforum.org/resources/practitioner-insights-federal-reserve-bank-sanfrancisco [http://perma.cc/AVC7-P9AN] (last visited Feb. 28, 2016).

175. See, e.g., Leonard J. Marcus et al., The Walk in the Woods: A Step-by-Step Method for Facilitating Interest-Based Negotiation and Conflict Resolution, 28 NEGOT. J.337, 339-40 (2012).

176. Kania \& Kramer, supra note 79, at 38-39.

177. Cities like Detroit are aggressively pursuing philanthropic support. See, e.g., Jennifer Chambers, New Detroit Hire Works To Keep Philanthropy Aid Flowing, Detroit News (June 9, 2015, 12:14 AM), http://www.detroitnews.com/story/news/local/detroit-city/2015/06/09/detroit- 
Funding is a particular challenge for collective impact initiatives because, by definition, collective impact initiatives fall outside the traditional pattern of nonprofit grant making. One of the most important unresolved questions for collective impact initiatives (and for collective impact problem solving more generally) is how foundations can be most constructive in supporting collaborative work that leads to collective action and generates large-scale impact. Under a typical granting scenario, a funder or its agent will assemble nonprofit and government agencies. ${ }^{178}$ They offer the prospect of grant dollars to motivate the group to develop a bold new solution to an entrenched social problem. ${ }^{179}$ Funders then try to find the best award recipient, which means that potential awardees compete against each other. This competition prevents broader community development because 1.4 million nonprofits try to create independent short-term solutions to social problems annually in order to obtain grant funds. ${ }^{180}$ To paraphrase a famous Hollywood actor, "if you're not a part of the solution, you're a part of the problem,",181 and traditional funding practices are proving problematic for grant recipients because those practices largely limit how grantees can spend grant funds. For example, it is not uncommon for a grant to fund the design and operations of a new program but not fund program staff. As one commentator noted, until more "funders are willing to embrace this new approach and invest sufficient resources in the necessary facilitation, coordination, and measurement that enable organizations to work in concert, the requisite infrastructure will not evolve." 182

In contrast to the traditional model, funders who invest in creating large-scale change through collective impact follow four recognizable practices: "take responsibility for assembling the elements of a solution; create a movement for change; include solutions from outside the nonprofit sector; and use actionable knowledge to influence behavior and improve performance." ${ }^{183}$ Collective impact

philathropy/28721791 [https://perma.cc/JMS8-MWAC]. Like the idea of collaboration, this is not necessarily new, but now city and state governments have at least one individual on staff who is specifically focused on philanthropic investment. $I d$.

178. See Douglas Easterling, Getting to Collective Impact, MARY ReynOldS BABCOCK Found. (Nov 20, 2013), http://mrbf.org/blog/getting-collective-impact [http://perma.cc/HY48F932].

179. Id.

180. Kania \& Kramer, supra note 79 , at 38.

181. Die HARD (Twentieth Century Fox 1988). The quote is also attributed to former Black Panther leader Eldridge Cleaver and is an African proverb. See, e.g., John Kifner, Eldridge Cleaver, Black Panther Who Became a G.O.P Conservative, Is Dead at 62, N.Y. Times (May 2, 1998), http://www.nytimes.com/1998/05/02/us/eldridge-cleaver-black-panther-who-became-gopconservative-is-dead-at-62.html [https://perma.cc/D28V-94PS].

182. Kania \& Kramer, supra note 79 , at 41.

183. Id. Related to this paradigm shift is a paradigm shift that forces funders to become less concerned with credit and attribution. Kim Fortunato, When and How To Engage the Private Sector in Collective Impact, Collective IMPACt F. (July 14, 2015, 9:12 PM), http://collective impactforum.org/blogs/9406/when-and-how-engage-private-sector-collective-impact 
is spearheading this new approach and in some sectors this is already happening. For example, the Ford Foundation recently announced changes in how the foundation funds its recipients because prioritizing specific project support over general operation support limited the work of its grant recipients to "incremental outputs" instead of long-term strategy. ${ }^{184}$ This is important because "achieving long-term financial sustainability" is the biggest challenge facing nonprofit organizations today. ${ }^{185}$ Now the Ford Foundation will focus on supporting "key anchor organizations" in its six program areas,${ }^{186}$ calling this shift "social justice philanthropy for the $21^{\text {st }}$ century." 187

A paradigm shift in funder norms and funding practices aligns well with collective impact as this shift will make more funding available to the backbone support organizations that manage collective impact initiatives.

c. New role for business interests and the private sector.-A third paradigm shift engendered by collective impact implicates the role of business and the private sector in initiating and supporting social change. Collective impact is an innovative blend of social and commercial interests and, accordingly, collective impact initiatives promote a variety of exchanges between the nonprofit and business industries. ${ }^{188}$ As a result, the private sector is gaining a new appreciation for the complexity of social issues. Likewise, nonprofit organizations are gaining a deeper awareness of potential partnerships in the business world as opposed to

[http://perma.cc/5MAC-ENJK].

184. See Darren Walker, What's Next for the Ford Foundation, Ford Found. (June 11, 2015), http://www.fordfoundation.org/equals-change/post/whats-next-for-the-ford-foundation [http://perma.cc/GA3A-YBFV].

185. Id.

186. The Ford Foundation's six program areas are as follows: (1) civic engagement and government; (2) creativity and free expression; (3) gender, ethnic, and racial justice; (4) inclusive economies; (5) internet freedom; and (6) youth opportunity and learning. Id.; see also Funder Insights: Ford Foundation, COLLECTIVE IMPACT F., http://collectiveimpactforum.org/resources/ funder-insights-ford-foundation [https://perma.cc/2Y24-5ZA2] (last visited Feb. 28, 2016); Forum for Community Solutions, ASPEN INST. (July 24, 2014), http://www.aspeninstitute.org/news/ 2014/07/24/aspen-institute-re-invests-innovative-community-collaboratives-engage-opportunity [https://perma.cc/3PU8-FATF].

187. See Walker, supra note 184. The Ford Foundation is not alone in exploring the potential for collective impact. The MacArthur Foundation supported Opportunity Chicago through its Partnership for New Communities. See A Collective Impact Case Study: Opportunity Chicago, MACARTHUR Found. (Oct. 7, 2013), http://www.macfound.org/press/publications/collectiveimpact-case-study-opportunity-chicago/\#sthash.1qyHXb5q.dpuf [http://perma.cc/GR3M-7QF5]. That collective impact initiative focused on workforce development and assisted 5000 public housing residents who were low-skilled, low-income job seekers with preparing for and finding quality jobs through workforce development resources. "Opportunity Chicago was a 'collective impact' effort that brought together government agencies, foundations, nonprofit organizations, and employers in a collaborative framework for development and integration of resources and services needed to meet the needs of the city's public housing residents." Id.

188. Fortunato, supra note 183. 
simply asking for financial support. ${ }^{189}$ In addition to financial support, the business community is providing collective impact initiatives with expertise and training in management, data collection and analysis. ${ }^{190}$ "Business organizations are taking on strong roles [in collective impact initiatives], serving as a founding partner or backbone organization, to represent the collective voice of the business community." "191 The renowned Campbell Soup Company, for example, implemented a ten-year, $\$ 10$ million collective impact initiative to reduce childhood hunger and obesity in Camden, New Jersey, where its headquarters are located. ${ }^{192}$

2. Manageable Risks in Collective Impact.-The adoption of any new strategy brings with it new risks; collective impact is no different. The risks and potential pitfalls associated with collective impact initiatives are both reminiscent of other social change strategies and uniquely associated with the collective impact framework. If not managed properly, these risks could impede collective impact and its utility for impact transaction. This section details three important but manageable risks inherent in collective impact and offers brief context for how these risks could be managed and, therefore, minimized, by a written collective impact agreement.

a. Exclusion of the targeted community.-Collective impact initiatives may be fairly criticized for being "grasstops" ${ }^{193}$ orientated instead of focused on

189. There are ten interesting lessons to appreciate about the involvement of business interests in collective impact:

1 -Outside language is [c]ollective [i]mpact-[i]nside [1] anguage is [p]roject [m]anagement ... 2- Collaboration is not natural for any of us, and it is even more challenging in the community ... 3- Year 1 of a collective impact initiative is like Year 1 of an entrepreneurial business venture ... 4- Getting the right people on the right bus is not a simple task . . . 5- People who need people CAN be the luckiest people but not always ... 6- People and the power dynamic of the funder can require a buffer . . . 7Re-up is part of the Analyze-Plan-Do-Check Plan . . . 8- Over communicate, even though there is no such thing as over communicating ... 9-Be intentional about equity and diversity that spans income, race, thought process and more . . 10- Leadership is not always easy, and sometimes lonely.

See 10 Lessons Learned from Engaging the Business Community in Collective Impact, COLLECTIVE IMPACT F.(July 14, 2015, 8:49 PM), http://collectiveimpactforum.org/blogs/1/10-lessons-learnedengaging-business-community-collective-impact [https://perma.cc/KV4X-V66R].

190. See Grossman et al., supra note 93, at 4-5.

191. Collective Impact for Education and Workforce Development, Ass'N CHAMBER COM. EXECUTIVES, http://www.acce.org/wiki/collective-impact-for-education-and-workforcedevelopment/ [https://perma.cc/9YA2-4ZDW] (last updated Feb. 25, 2016) (discussing the increasing role of chambers of commerce as backbone support organizations in collective impact initiatives).

192. Fortunato, supra note 183.

193. See Melody Barnes et al., Roundtable on Community Engagement and Collective Impact in COLLECTIVE InSIGHTS ON COLLECTIVE IMPACT 12, 14 (2014), available at http://ssir.org/articles/ entry/roundtable_on_community_engagement_and_collective_impact [https://perma.cc/Y46P- 
"grassroots" organizing, meaning institutions are making decisions about the communities in which they are trying to promote social change without engaging the impacted community, if at all, until an initiative is well underway. Although this is a fair and realistic critique of many past social change efforts, particularly those related to community development, ${ }^{194}$ it is equally true for many potential collective impact initiatives involved with underserved communities of color. ${ }^{195}$

When impacted communities are excluded from or have limited involvement in collective impact initiatives, private foundation and corporate interests become exaggerated and their voices dominate leadership and goal setting. Such an outcome is possible because there is no prescribed role for the target community in the collective impact initiative-excluding the necessity of its existence. Collective impact suffers from some of the same limitations as other social change efforts, including weak success rates with providing opportunities for and securing meaningful involvement from the targeted communities. ${ }^{196}$ To be truly successful, collective impact initiatives must include community representation at the same level of involvement as the other participants. Too often in social change efforts the affected community is involved as a special project or an afterthought. The community's participation, however, must be as organic to a collective impact initiative as the participation of the backbone agency and the other participants. The risk of falling into historic patterns of excluding or minimizing community involvement can be managed through the creation of thoughtful and innovative collective impact governance structures that mandate community involvement and a written collective impact agreement that incorporates these governance structures by reference and to which some representation of the community is a signatory. ${ }^{197}$

b. Unsustainability.-Given the nascent nature and unprecedented scope of collective impact, there is a risk the work cannot be sustained. In addition, the success of a collective impact initiative is largely reliant on the dependability and skill set of the backbone agency and the collegiality among the initiative participants. ${ }^{198}$ This underscores a dependency on backbone agencies and places these organizations in a tremendous position of power as elite members of a small class of project managers for collective impact initiatives. Although there is no good replacement for the passage of time to test collective impact strategy, this

$8 \mathrm{E} 3 \mathrm{Q}]$.

194. See generally Patience A. Crowder, "Ain't No Sunshine": Examining Informality and State Open Meetings Acts as the Anti-Public Norm in Inner-City Redevelopment Deal Making, 74 TENN. L. REv. 623 (2007).

195. See Why Communities of Color Are Getting Frustrated with Collective Impact, NonPROFIT With BALLS (Nov. 29, 2015), http://nonprofitwithballs.com/2015/11/whycommunities-of-color-are-getting-frustrated-with-collective-impact/ [https://perma.cc/YM4QD4Q5].

196. Id.

197. This suggestion is not made lightly considering the well-documented challenges with identifying "the community" for these sorts of transactions.

198. See generally JoLIN ET AL.., supra note 85 . 
risk could be managed through a written collective impact agreement that will legislate transparency, set expectations for the participants' behavior, and manage accountability. In addition, this agreement could speak directly to the role and behavior of the backbone agency by incorporating an evaluation component or rating system to ensure a balance of power with in a collective impact network.

c. Mini-coalitions and holdouts.-As can happen with any coalition, there is a risk in collective impact cliques might form within collective impact initiatives and form mini-coalitions that are politically divisive. Along the same lines, a party contributing a particularly unique service might try to hold out for a larger planning role, more authority, or financial compensation because of the perception no other entity can provide the same. ${ }^{199}$ This risk can also be managed through a written collective impact agreement that incorporates covenants to prohibit this type of behavior as well as consequences for it.

\section{Actualizing the Value and Minimizing the Risks of Collective Impact Through Written Agreement}

Collective impact is a process that operates in distinct phases. The initial phases involve the issuance of the first RFP by the funder or the backbone agency to find non-backbone participants and secure letters of commitment from individual participants. ${ }^{200} \mathrm{~A}$ collective impact initiative begins with a funder's identification of an adaptive problem, the successful treatment of which could lead to social change. ${ }^{201}$ From there in loose chronological order, the funder will begin working with a collective impact consultant to retain a backbone agency and other participants in the collective impact initiative. ${ }^{202}$ Once the participant roster is finalized, the backbone will manage the formation of (i) a steering committee, which has a governance effect similar to that of an executive committee of a board of directors and (ii) thematic working groups responsible for a range of activities from data collection to community outreach. Next, members of collective impact initiatives "agree to agree," 203 then begin an intensive planning process through which they build up trust and an appreciation

199. See, e.g., Robert H. Mnookin, Strategic Barriers to Dispute Resolution: A Comparison of Bilateral and Multilateral Negotiations, 8 HARV. NeGOT. L. REV. 1, 15 (2003).

200. See Kania \& Kramer, supra note 79 , at 40.

201. Id. at 39 ("Collective impact requires all participants to have a shared vision for change, one that includes a common understanding of the problem ....").

202. See generally id.

203. Generally, courts treat "agreements to agree" as unenforceable, although a number of legal scholars have suggested this distinction between a contract and negotiations preceding contract formation is overly formalistic and should be reconsidered. See Thomas J. Stipanowich, Contract and Conflict Management, 2001 WIS. L. REV. 831 (2001) (citing Ian R. Macneil, A Primer of Contract Planning, 48 S. CAL. L. REV. 627 (1975), throughout). This Article focuses on the value of a written agreement to effectuate collective impact initiatives and it is beyond the scope of this Article to assess the applicability of any implied contract law principles to collective impact initiatives that occur in the absence of a written agreement. 
for each other's perspectives as they work toward a common goal. ${ }^{204}$

Collective impact initiatives are built around a system of deepening relationships between the participants. During this early planning process, the members of the collective impact are brainstorming to determine the outcomes of the initiative, but they are not brainstorming about how those outcomes will be accomplished by the individual members of the working group. ${ }^{205}$ That comes later in the process when those particular questions become "ripe" for strategy discussions. ${ }^{206}$ Planning continues as the initiative moves forward and the parties' obligations are frequently unclear until a specific need arises as determined by the planning process. ${ }^{207}$ "There is no fast way to do this work. The focus needs to be on the process, not a product. At the same time, you need to work with a burning patience. ${ }^{208}$ Until then, the participants value the flexibility the process permits and the time to build and foster relationships among the participants-forming relational contracts - and doing so in the absence of any written contract. ${ }^{209}$

A written agreement is the most effective way to actualize the value and minimize the risks of collective impact. Far too frequently, collective impact initiatives are traversed without an agreement to document the expectations of the participants. ${ }^{210}$ This means it is not uncommon for members of collective impact initiatives to participate in these initiatives without binding documents that memorialize each party's expectations, responsibilities, and obligations-unlike what typically occurs in multi-party transactions in other disciplines. For example, when a bank syndicate makes a loan to a borrower, the relationship among the various banks and the borrower is governed by a credit agreement. ${ }^{211}$ That credit agreement documents obligations, including the total loan amount, the amount of each individual bank's participation in the loan, the conditions

204. Building trust may take years in many cases. Kania \& Kramer, supra note 79, at 40.

205. Id. at 39 .

206. Id.

207. See generally id. at 40 ("Collective impact initiatives depend on a diverse group of stakeholders working together, not by requiring that all participants do the same thing, but by encouraging each participant to undertake the specific set of activities at which it excels in a way that supports and is coordinated with the actions of others.").

208. Ready by 21 St. Louis, Moving Toward Collective ImpaCt 4 (2014), available at http://ninenet.org/wp-content/uploads/2014/04/ReadyBy21_Spring2014.pdf [perma.cc/FEU8LLDZ] (quoting a United Way representative participating in collective impact).

209. See generally Kania \& Kramer, supra note 79, at 40 (discussing the importance of time and interactions between participants of a collective impact to develop trust among them).

210. The Author interviewed two collective impact consultants and one backbone agency, each in Denver, Colorado. All stated written agreements were rarely used to document collective impact agreements and acknowledged there would be use for a form collective impact agreement if drafted to reflect collective impact principles.

211. Large commercial loans are typically governed by a system of related agreements in addition to the credit agreement, including a security agreement, guaranty, or intercreditor agreement. For the purposes of simplicity, however, the focus of this example is only on the credit agreement. 
precedent to closing the loan, the rate of interest applied to the loan, the loan term, affirmative covenants (things the borrower must do to stay in compliance with the agreement), negative covenants (things the borrower should not do while under the agreement), events of default (things the borrower can do to default under the agreement), the various representations and warranties that the borrower must make about its capacity to participate in and repay the loan, and the required steps the borrower must draw from the loan.

Similarly, consider the impact litigation and impact transaction discussion in Part I. Where there are multiple lawyers and law firms representing plaintiffs in impact litigation, the lawyers negotiate and execute co-counsel agreements that govern a range of matters including decision-making, payment of litigation expenses, maintenance of client records, public relations, malpractice coverage, and dispute resolution.

By navigating collective impact initiatives without executing binding agreements to set the parties' expectations, members in collective impact initiatives are deliberately choosing to operate in the face of risk. This, participants say, is because they trust each other ${ }^{212}$ and this trust has the effect of minimizing any perceived risks. "Risks" are typically defined as "future events or conditions that have some probability of occurring" where any such occurrence will impact a project. ${ }^{213}$ Positive and negative risks are inherent in any project. "Negative risk is represented by potential events that could harm the project. In general, these risks are to be avoided. Positive risk, on the other hand, refers to risk [that actors chose to] initiate because they see a potential opportunity, along with a potential for failure." 214

Collective impact initiatives are explorations in positive and negative risk. There is negative risk because these initiatives are generally undertaken in the absence of an executed agreement, which has the strong potential to cause confusion about the parties' roles and increase their individual liabilities related to their participation in any given initiative. Any event arising from the absence of the agreement that harms the collective impact initiative results from this negative risk. The absence of an agreement, however, is also perceived as a positive risk by collective impact participants. This is because navigating a collective impact initiative without an executed agreement reflects the expectation of trust and flexibility demanded by the collective impact mindset and, perhaps, assumed to be integral to the initiative's success. Harkening back to the credit

212. See Kania \& Kramer, supra note 79 , at 40.

213. Tom Mochal, Take Positive Risks To Gain Project Benefits, TechRePublic (Jan. 7, 2008), http://www.techrepublic.com/blog/tech-decision-maker/take-positive-risks-to-gain-projectbenefits [www.perma.cc/T3VA-EN4U]; see also "We like to say that the partnership moves at the speed of trust." Grossman et al., supra note 93, at 4.

214. Mochal, supra note 213 ('Positive risk is also called 'opportunity risk.' In these instances, the project manager or project team may introduce risk to try to gain much more value later. A key aspect of positive risk is that you put yourself in a position to take on the risks; they are risks that we knowingly take upon ourselves because we perceive there to be advantages to doing so."). This is a hot topic in the project management and risk management fields right now. 
agreement analogy, each lender that is party to the credit agreement agrees to its participation amount of the total loan being made to the borrower. In contrast, in collective impact the members agree to the desired outcome(s) of the initiative and the common agenda, (the total loan amount in the credit agreement analogy), but not on how each member will specifically contribute to the accomplishment of the agreed upon outcomes (each bank's individual contribution). The collective impact participants willingly take this risk and the next Part demonstrates how relational contract theory both minimizes this risk and actualizes the unquantifiable value of the paradigm shifts ignited by collective impact.

\section{Positive Risk: Relational Contract Theory and Contracting Collective IMPACT}

This Article asserts the creation of a collective impact contracting process could mute or mitigate both negative and positive risks discussed in the previous Part to increase the likelihood of a positive social change outcome while respecting and preserving the collective impact mindset-and thus, facilitating impact transaction. According to relational contract theory, contracts involve more than discrete exchanges between parties and "every time a relationship seems properly to enjoy the label 'contracts' there is, or has been, some cooperation between or among the people connected with it." ${ }^{215}$ Relational contract theory is, arguably, modern contract law's most significant contribution to contract theory. ${ }^{216}$

Previous scholarship mostly dealt with relational contract theory in certain commercial contexts such as contracts for goods, commercial services, and employment; distribution, franchise, and other agency-based agreements; and, the foundational example of relational contract, marriage. ${ }^{217}$ This Article employs relational contract theory in a public interest context to elucidate the structure of collective impact and collective impact agreements. It is one of the first articles to explore the application of relational contract theory to questions of social change and to demonstrate the utility of relational contract theory for contracts in the public interest, specifically collective impact agreements.

This Part presents the evolution of relational contract theory, ${ }^{218}$ explains collective impact initiatives are relational contracts, and explains why there should be a written collective impact agreement that reflects relational contract principles to enhance the collective impact framework and facilitate impact

215. Ian R. Macneil, Whither Contracts?, 21 J. Legal Educ. 403, 404 (1969).

216. See Richard Austen-Baker, A Relational Law of Contract?, 20 J. ConT. L. 125 (2004).

217. See generally Elizabeth S. Scott \& Robert E. Scott, Marriage as Relational Contract, 84 VA. L. REV. 1225 (1998); see also Richard E. Speidel, The Characteristics and Challenges of Relational Contracts, 94 Nw. U. L. REv. 823, 823-24 (2000) (discussing different articles about relational contract theory).

218. This review is intentionally brief as there are many published detailed accounts of the origins of relational contract theory. What this Article contributes to that discussion is grounding the theory in a social change methodology. 
transaction.

\section{A. The Evolution of Relational Contract Theory and the Importance of Context in Contract}

Since Professor Ian Macneil's introduction of relational contract theory, ${ }^{219}$ numerous scholars, academics, and practitioners have contributed to the conversation, revealing a rich mix of opinions on the utility of relational contract theory. ${ }^{220}$ There are generally two veins of relational contract theory scholarship-one focused on how courts should interpret terms in relational contracts and the other on the parties' reliance on informal sanctions to encourage each other to keep their promises. ${ }^{221}$ Although there is general acceptance that contracts are relational, albeit at varying points on the continuum of relationality, there is a fair amount of disagreement among scholars about the best way to enforce relational contracts. ${ }^{22}$ This Article saves that question for later scholarship. Thus, instead of reviewing the scholarship on relational contract theory generally (which has been done in great detail by other scholars), ${ }^{223}$ this Article starts from the premise that relational contract theory is a significant contribution to contract law and practice and proceeds to demonstrate the theory's applicability to collective impact.

219. The New Social Contract: An Inquiry into Modern Contractual Relations is the foundation of relational contract theory. IAN R. MACNEIL, THE NEW Social CONTRACT: AN InQuiry Into Modern Contractual Relations (Yale Univ. Press 1980). The thesis emphasizes contact law primarily focuses on remedies for breaches of discrete contracts and significantly lacks an understanding of how contracts operate in real-world exchanges. Id. Previously, Macneil argued the importance of relationships in economic behavior and the shifting nature of contractual relationships in the modern world, due to the increase in the ability for consumers to consciously choose whom to contract with. Macneil, Futures, supra note 42, at 710. However, he argued none of these transactions occurred in "a social vacuum." Id. Macneil's theory shifted to "essential contact theory," which applies his theory of relational contracts to "common contract behavior and norms." Ian R. Macneil, Relational Contract Theory: Challenges and Queries, 94 Nw. U. L. REV. 877, 877 (2000) [hereinafter Macneil, Challenges]. Essential contract theory is a means for applying relational contract theory to real-world transactions by encompassing certain assumptions of human behavior, social norms, contract law, and transactional norms.

220. See, e.g., Scott \& Scott, supra note 217; see also David V. Snyder, Language and Formalities in Commercial Contracts: A Defense of Custom and Conduct, 54 SMU L. REv. 617, 619 (2001).

221. See Scott Baker \& Albert Choi, Contract's Role in Relational Contract, 101 VA. L. REV. 559, 567-68 (2015).

222. See, e.g., Charles C. Goetz \& Robert E. Scott, Principles of Relational Contracts, 67 VA. L. REV. 1089 (1981).

223. See Melvin A. Eisenberg, Why There Is No Law of Relational Contracts, 94 Nw. U. L. Rev. 805 (2000); Ethan J. Leib, Contracts and Friendships, 59 EMORY L.J. 649, 673-725 (2010); Austen-Baker, supra note 216; Goetz \& Scott, supra note 222; Macneil, Challenges, supra note 219. 
1. From Classical to Modern Contract Law.-Contract law first emerged under the school of classical contract law (or "conventional" or "traditional"), ${ }^{224}$ which holds very fixed definitions for the dimensions of contract. Under classical legal analysis, the paradigmatic contract is an isolated discrete exchange between strangers in a market where the parties are able to "at minimal cost . . . allocate explicitly the risks that future contingencies may cause one or the other to regret having entered in to an executory agreement." ${ }^{225}$ Thus, in accordance with these dimensions, classical contract law is stiff and has no room for understanding or appreciation of subjective context in transactions. ${ }^{226}$ In addition, this lean interpretation holds no space for "justifying doctrinal propositions on the basis of social propositions - that is, propositions of morality, policy, and experience." ${ }^{227}$ Unfairness and unconscionability have no home in classical contract law, which presumes a focus on the objective and standardized. ${ }^{228}$ Ideally, this rigidity in contract interpretation and analysis promotes predictable outcomes in dispute resolution. Realistically, however, the world is more complex than what classical legal analysis can effectively process. ${ }^{229}$ Perfect markets are rarer than pink unicorns and even rarer are contracts made in perfect markets between strangers who have no prior knowledge of each other in any context or will never contract with each other again in any context. ${ }^{230}$

Modern contract law arrived to provide for more realistic and practical contract interpretation and in direct response to the limitations of classical contract law. ${ }^{231}$ Accordingly, contemporary contract law scholars believe that "contract law reasoning should be substantive rather than formal, and ... the rules of contract law should, where appropriate, be individualized rather standardized, subjective rather than objective, complex rather than binary, and dynamic rather than static." ${ }^{232}$ In other words, modern contract law is a fluid frame in which contractual relationships are free to form in accordance with their

224. These terms are used interchangeably in relational contract theory scholarship; however, this Article uses the term "classical."

225. This narrow conception of contract law led Grant Gilmore to write The Death of Contract in which he argued that all contracts are individual and discrete interactions and that, as such, there was little value in continuing to teach contract law as a doctrinal course in the law school curriculum because there was no comprehensive theory of contract law to teach to students. GRANT Gilmore, The Death of Contract (1st ed. 1974); Goetz \& Scott, supra note 222, at 1089-90.

226. See Eisenberg, supra note 223, at 805.

227. See DiMatteo \& Morant, supra note 54, at 569 ("The lack of acknowledgment of cultural, class, and racial factors in the interpretation and enforcement of contracts - bias and discrimination issues aside- relates partially to contact law's egalitarian underpinnings.").

228. See Eisenberg, supra note 223, at 807.

229. Ian Macneil asserted the prevalence of relation is constantly increasing in the postindustrial socioeconomic world. See Macneil, Futures, supra note 42, at 694-95.

230. See Eisenberg, supra note 223, at 805.

231. See Melvin A. Eisenberg, The Emergence of Dynamic Contract Law, 88 CAL. L. REV. 1743,1745 (2000).

232. Id. at 1745 . 
specific conditions - bounded by contract law at the macro level. Critiques of classical contract law cut to the fundamental core of its doctrine. ${ }^{233}$ Melvin Eisenberg provided a framework to distinguish modern contract law from classical contract law. ${ }^{234}$ Eisenberg's framework speaks to the importance of context in contract interpretation in opposition to the flawed and impractical logic of classical contract law. Modern contract law reasoning and rules have evolved to reflect these assertions. "[M] odern contract law has appropriately moved from a static conception of interpretation, that tended to focus on the text as of the moment of contract formation, to a dynamic conception, that encompasses events before and after that moment." ${ }^{, 35}$ Thus, this shift made space for relational contract theorists to urge that the text of a contract "runs through time."

2. The Emergence of Relational Contract Theory.-The differences between classical contract law and modern contract law are profound. Modern contract law has made a number of dynamic departures from the static offer-andacceptance model of classical contract law. ${ }^{236}$ Among these departures are rules that recognize the formation of a contract may be a dynamic, evolving process, rather than a process that can be located at a fixed moment in time. ${ }^{237}$

Relational contract theory is a direct response to "two of the fundamental weaknesses of classical contract law-its static character, and ... its implicit[ly] empirical premise [and flawed assumption] that most contracts are discrete."238 In contrast to the austerity of classical contract, relational contract theory contemplates "indefiniteness, agreements to agree, and agreements to negotiate in good faith." 239 As a component of modern contract law based on "the paradigm of transactions by actors who are in an ongoing relationship," relational contract theory is an open, inductive, dynamic, and individualized mechanism of contract interpretation. ${ }^{240}$

Although there is no singular definition of relational contract, most scholars would agree that "[a] contract is relational to the extent that the parties are incapable of reducing important terms of the arrangement to well-defined obligations" ${ }^{241}$ where "[s]uch definitive obligations may be impractical because of inability to identity uncertain future conditions or because of inability to characterize complex adaptions adequately even when the contingencies

233. See generally Eisenberg, supra note 223, at 807-13.

234. Namely, that: (1) "Law Must be Justified by Social propositions;" (2) "Many Rules of Contract Law Should be Individualized, Subjective, or Both;" (3) "Contract Law Should Take Account of the Dynamic Aspects of the Contracting Process;" (4) "The Paradigmatic Case of Classical Contract Law is an Abnormal Case;" (5) "Rational-Actor Psychology Does Not Adequately Explain the Behavior of Contracting Parties." Id. at 808-13.

235. Eisenberg, supra note 231, at 1770.

236. Id. at 1751-52.

237. Id. at 1796.

238. See Eisenberg, supra note 223, at 821.

239. See id. at 817.

240. See id. at 812-13.

241. See id. at 815 . 
themselves can be identified in advance." ${ }^{242}$ Ian Macneil identified the following four core propositions of relational contract theory. ${ }^{243}$

a. Every transaction is embedded in complex relations.-Every exchange occurs in the context of a social matrix that provides at least (1) a form of communication both parties understand, (2) a social order that governs the parties' behavior so one party does not steal the contracted object from the other, (3) a form of currency, and (4) an effective mechanism for enforcing promises. ${ }^{244}$

$b$. Understanding any transaction requires understanding all essential elements of its enveloping relations that might affect the transaction significantly.-It is important the parties stretch their perspectives to consider all aspects of the transaction, even those that might not actually be reflected in the final version of the agreement. ${ }^{245}$

c. Effective analysis of any transaction requires recognition and consideration of all significant essential elements.—"Recognition and consideration of all significant relational elements becomes particularly essential where the subject of examination is behavioral aspects, such as the structuring of contractual relations in which transactions occur, including all questions of law pertinent to them." 246

d. Combined contextual analysis of relations and transactions is more efficient and produces a more complete and sure final analytical product than does commencing with non-contextual analysis of transactions. - A comprehensive approach to this analysis is more efficient than beginning the analysis from the narrowest perspective. ${ }^{247}$

Many scholars, however, question the need for any distinctions between relational contracts and discrete contracts. ${ }^{248}$ During the earliest articulations of the relational contract theory, there were questions about the need for a new body of contract law to address relational contract theory or at least for special rules to govern relational contracts. ${ }^{249}$ Neither of those ideas have come to fruition mostly because of the presumed pervasiveness of relational contracts, meaning, for some, all contracts are relational to some degree or another and there are no bright lines to distinguish between relational and discrete contacts. ${ }^{250}$

Although relational contracts have no succinct definition or predictable party-

242. Goetz \& Scott, supra note 222, at 1091.

243. Macneil, Challenges, supra note 219, at 881.

244. See id. at 884.

245. See generally id.

246. See id. at 887 . The suggestion here is not to perform an entirely new inquiry with each subsequent transaction or transaction-type. That would defeat efficiencies inherent in transactional practice. The point is to highlight the importance of the need to be mindful of this proposition so as not to miss the need should it ever arise. See id.

247. See id. at 888 .

248. See, e.g., Eisenberg, supra note 223, at 813-17 (suggesting that "[d]iscrete contractscontracts that are not relational- are almost as imaginary as unicorns").

249. See id. at 817-18.

250. “All contracts are relational." Id. at 817; see also Austen-Baker, supra note 216. 
types, relational contracts have come to be identified by a list of characteristics that include: indefiniteness about duration; informality of language; incompleteness $;{ }^{251}$ imprecise performance standards; expectations of the role for social norms and social control; reference to industry standards $;^{252}$ and gaps in risk allocation. It is precisely the nature of the characteristics that encourage parties to seek out and enter into relational contracts.

Parties enter into relational contracts because such agreements present an opportunity to exploit certain economies. Each party wants a share of the benefits resulting from these economies and consequently seeks to structure the relationships so as to induce the other party to share the benefits of the exchange. Typically, this is accomplished by specifying the performance standard of each party and then selecting a mechanism to ensure compliance with the agreed-upon standard. ${ }^{253}$

In the case of collective impact initiatives, the "economies" referenced above are the grant funds managed by the backbone agency, as linked to an individual organization's contribution to a collective impact initiative's targeted social change. As explained, collective impact participants are specifically attracted to these initiatives because of the framework's deliberately collaborative methodology. The next section demonstrates where these characteristics of relational contract link with collective impact framework and collective impact agreements.

3. The Relationality of Collective Impact. - W ith the advancement of modern contract law came an appreciation for context in contract. ${ }^{254}$ Modern contact law,

251. See Robert E. Scott, The Case for Formalism in Relational Contract, 94 Nw. U. L. REv. 847,862 (2000).

252. But see Leib, supra note 223, at 662 (discussing the importance of applying "loose standards [rather] than formalistic rules" to relational contracts).

253. Goetz \& Scott, supra note 222, at 1092. The same is true for collective impact agreements and collective impact participants should craft performance standards that are actually reflective of the collective impact methodology.

254. Recognition of the influence of external and internal factors is critical to a "prescriptive view," a view that encompasses the contextual reality of a transaction. DiMatteo \& Morant, supra note 54, at 553. External factors, including race, gender, and socioeconomic status, and internal evaluations of how contracts as a body of law relates to contracts in real-world transactions is necessary for a "prescriptive view" of contractual relations. "[T]he tensions between formal and contextual, internal and external, and deduction and induction are constant." Id. at 553. Although contract law does incorporate some doctrines that allow the law to consider contextual factors, there is a debate on if the factors, including "duress, undue influence, misrepresentation, and unconscionability," are enough to mitigate external factors such as "race, gender, or lack of business sophistication." Id. at 565. This argument further calls for an evaluation of the "reasonable person" standard. Although the general belief in a reasonable person is important to judicial economy, the definition excludes external factors, e.g., lack of business understanding or significantly lower education, which largely affects individuals with a lower socioeconomic status, racial minorities, and women. Incorporation of contextual principles to contract interpretation could expand the reasonable person standard to account for these external influences on internal contract 
generally, and relational contract theory, specifically, recognizes "context-driven distinctions." 255

A contextual theory of contract law recognizes the need for flexible rules for different contractual contexts and the elastic application of those rules across contexts. A contextual theory of contact law also recognizes a number of phenomena. First, contract interpretation, through the lens of context, should be used to regulate influences that question the purity of the freedom of contract upon which most agreements are based. Second, the construct of contract has been creatively applied to areas that are not immediately envisioned within the body of contract law. ${ }^{256}$

Relationists argue that "[c]ontract law, which orders bargaining relationships and transactions, should always be tempered by the facts of particular contexts." "257 "Context" is a broad concept best perceived comprehensively. Context is the substance of the deal, the circumstances under which the deal was made, the course of dealing between the parties, the industry(ies) in which the parties operate, and "the asymmetrical information or power disparities"258 present in the transaction.

As contract law evolved from classical to modern, the notion of context became less benign to contract formation and interpretation. ${ }^{259}$ The question of the importance of context to contract, however, is far from resolved. ${ }^{260}$ Context is, however, fundamentally important to the formation of relational contracts, including collective impact initiatives. As explained earlier, collective impact initiatives are built around certain conditions for success; specifically they must demonstrate a common agenda, shared measurement, mutually reinforcing activities, continuous communication, and sufficient backbone support. These five conditions for success provide the framework of context for each collective impact initiative, meaning the five conditions create the contextual frame of each collective impact initiative. ${ }^{261}$ The parties discuss and select the common agenda, negotiate the logistics behind the development of the mechanisms for shared measurement and continuous communication, identify and agree to perform mutually reinforcing activities that advance the initiative, and, perhaps with the funder or a consultant, the backbone agency works to find participants for the initiative. ${ }^{262}$

law structure. $I d$.

255. Id. at 557 .

256. Id. at 554 .

257. Id. at 561 .

258. Id. at 557 .

259. See generally id.

260. "The lack of acknowledgment of cultural, class, and racial factors in the interpretation and enforcement of contracts - bias and discrimination issues aside - relates partially to contract law's egalitarian underpinnings." Id. at 559.

261. See Kania \& Kramer, supra note 79, at 5-6.

262. Id. 
As previously explained, collective impact initiatives are relational contracts that would greatly benefit from being documented in written agreements. ${ }^{263}$ An analogy to the construction industry helps illustrate this point. There are strong similarities between the construction industry and collective impact. Attention to relationships rings true in the construction industry, for "[e]xperienced owners and contractors, and their seasoned lawyers, often observe that a project's success depends more on establishing and managing the relationships between the participants than on the contracts they execute. ${ }^{264}$ Like collective impact, most construction contracts involve multiple parties, including property owners, general contractors, subcontractors, architects, and engineers. Also like collective impact, most construction projects are long-term projects accomplished in phases over a period of time. Relationality is so fundamental to the construction industry that relational aspects of contracting are reflected in the construction industry's standard form documents. ${ }^{265}$ Moreover, it is generally accepted in the construction industry that the primary function of a construction contract "is not to predict or control all contingencies that may arise in the future but to create a workable framework for managing successful relationships." ${ }^{266}$ Thus, the construction industry demonstrates the range of relationality-from relationship management to the form documents produced by the industry trade associations. The recognition of construction contracts as relational contracts provided the construction industry with a much-needed framework for managing and papering construction transactions and provides a strong precedent for collective impact.

Similarly, relational contract theory provides guidance to collective impact initiative participants (and their lawyers) about how to navigate collective impact planning processes properly, how to approach drafting collective impact agreements, how to approach funders about what to expect and require from collective impact initiatives, and, indirectly, how to approach the courts about resolving collective impact disputes. ${ }^{267}$

While national private foundations presumably have strong networks and significant legal resources to obtain the appropriate documentation necessary for the collective impact initiatives they fund, these concepts are particularly important for the "middle market" local nonprofits that lack those resources but, nonetheless, want to participate in collective impact initiatives. This is the next step in the discipline of transactional law: making a larger societal impact by forging agreements between parties towards a common goal. This new discipline, impact transaction, begins here: by connecting collective impact with relational contract theory to develop a framework for impact transaction contract principles.

263. See supra Part III.

264. See Carl J. Circo, The Evolving Role of Relational Contract in Construction Law, 32 Construction Law. 16, 16 (2012).

265. See id.

266. Id. at 20.

267. See infra Part IV.A-B. 


\section{B. Why Collective Impact Needs a Written Contact}

Having established collective impact is relational, the next question is to explore whether collective impact as a relational contract should be documented by a written collective impact agreement. This is a timely question as collective impact continues to grow in popularity as a tool for social change without normalizing a collective impact agreement.

This Article argues for the value of the written agreement in collective impact. This Article does not simply raise doctrinal concerns; it provides practical considerations that warrant the execution of enforceable collective impact agreements. For example, there are conditions precedent in collective impact initiatives that must be orchestrated to account for: (i) allowing the parties to understand when their obligations are triggered by the actions of another party to the agreement; (ii) when collective impact initiatives around topics such as education or workforce training produce curricula that raise questions about the ownership of intellectual property; and (iii) when activities undertaken in pursuit of the shared agenda implicate liability concerns, or, at the least, should be traceable to performance of each party. For these and other reasons, a written collective impact agreement is a good idea.

A properly drafted collective impact agreement will document "shared accountability and differentiated responsibility' among stakeholders" where "[e]ach stakeholder had 'a defined role in achieving a shared vision of improved outcomes. ${ }^{268}$ Under the current practice, however, collective impact agreements, if drafted at all, are drafted as largely aspirational and the agreements are not typically structured to identify which parties are responsible for what deliverables at any particular phase of the initiative-an outcome counter to certain fundamentals of contract law. ${ }^{269}$

Written relational contracts are, by definition, incomplete. Incomplete contracts are "[1]ess-complete contracts that rely on trust and reciprocity rather than control."270 Typical reasons that explain why parties might enter into incomplete contracts include (i) potential high transaction costs difficult to estimate in light of an unknown or unpredictable future, and (ii) asymmetric information between the parties that one or both parties is unwilling to share. ${ }^{271}$ Incomplete contracts are not substantively flawed. ${ }^{272}$ It is a strategic decision to enter into an incomplete contract. ${ }^{273}$ Collective impact is a relational phenomena that requires expression in written collective impact agreements to reach its full

268. See Grossman et al., supra note 93 , at 4.

269. A contract is "the projection of exchange into the future." Macneil, Futures, supra note 42 , at $712-13$.

270. See Wendy Netter Epstein, Facilitating Incomplete Contracts, 65 CASE W. RES. L. REV. 297, 300 (2014).

271. See Scott, supra note 251, at 862-63.

272. See Epstein, supra note 270 , at 300.

273. $I d$. 
potential. There are two primary reasons to encourage the normalization of collective impact agreements into the collective impact toolkit, namely (1) notions of neoformalism that promote the values of efficiency and uniformity and (2) public policy.

Scholars have argued both for and against neoformalism. ${ }^{274}$ The most strident arguments in favor of neoformalism assert formalism is warranted to provide relational contract interpretive strategies for courts and other decision makers. ${ }^{275}$ This is an argument for judicial efficiency. The counterargument to neoformalism, however, is it could be used to marginalize the "real deal that parties enter into and rely on within relational contracts." 276 In other words, neoformalism could alter a relational contract beyond the bounds where it is no longer the deal the parties believe they entered into-a certain type of transactional inefficiency. ${ }^{277}$ In other words, to the extent relational contracts respect the expectations of the parties where the document was silent; there is justice for the parties to the contract. ${ }^{278}$ Neoformalism then, to the extent it moves a contract beyond the parties' expectations, would be injustice. ${ }^{279}$

Although relationists prefer standards over rules, ${ }^{280}$ neoformalism, which prefers language and formality, ${ }^{281}$ "recognizes that even parties embedded in a complex relationship may nevertheless prefer to be governed under a formalism system." 282

To date, the question of formalism in relational contract was a matter of contract interpretation in litigation or some mechanism for dispute resolution. Here, the question is not about filling gaps in disputed contracts (at the back end of a deal), but looking forward during the commencement of the relationship, throughout the planning process, and the drafting of the collective impact agreement (at the front end). Instead of contemplating dispute resolution after a conflict arises, neoformalism speaks to the formation and structure of the transaction. Formalism completes the agreement ex post through dispute resolution. Creating a term sheet to use as contemplated in the next section would

274. Compare Scott, supra note 251, at 869 (arguing for formalism), with Leib, supra note 224, at 715 (arguing against formalism).

275. See generally Scott, supra note 251 , at 869 . This keeps courts functioning at optimal levels. See also Baker \& Choi, supra note 221, at 559 (arguing for formalism to enable parties to design their own remedies for breach of contract).

276. See Leib, supra note 223 , at 715 .

277. Although the counterargument to this counterargument is parties should be held responsible for the deals they make, including any errors they make when considering entering those deals. See generally Ian R. Macneil, Contracts: Adjustment of Long-Term Economic Relations Under Classical, Neoclassical, and Relational Contract Law, 72 Nw. U. L. REv. 854 (1978).

278. Relational Contracting in a Digital Age, supra note 48, at 681 (Kidwell comments).

279. See generally Leib, supra note 223, at 715-16.

280. See id. at 667.

281. See Snyder, supra note 220 , at 619.

282. Id. at 677-78. 
force the consideration of certain types of provisions in the planning and drafting stages of the collective impact agreement.

Collective impact initiatives are conglomerations of relationships. Despite their diverse backgrounds and perspectives, members of collective impact networks are bound by a shared desire for social change and an abiding trust in the collective impact process. ${ }^{283}$ The argument for an agreement, therefore, appears to be a neoformalist argument counter to the culture of trust which is fundamental to the core of collective impact; trust is important to the formation and sustainability of collective impact initiatives. ${ }^{284}$ Trust and a shared desire for social change are the bookends to collective impact initiatives, framing the context of the five conditions for success. Both speak to the ongoing, but incomplete nature of relational contracts where, because of this "incompleteness," the importance of trust and loyalty become more pronounced. ${ }^{285}$ As demonstrated, however, there are important reasons for encouraging written collective impact agreements. This tension, if left unchecked, will limit the effectiveness of collective impact to be a replicable model for systemic social change as an impact transaction strategy. ${ }^{286}$

\section{Neoformalist Values: Efficiency and Uniformity}

The following scenarios promote both efficiency in contract by increasing the information available to collective impact participants and uniformity in the collective impact process by laying the groundwork for replicable processes in collective impact that can be adopted by other collective impact initiatives.

A written agreement would reflect and protect the individual and collective interests present in a collective impact initiative by setting expectations about the parties' roles and responsibilities. Although collective impact initiatives are built around a common agenda, each participant also has a self-interest in its participation and a written agreement would, ideally, protect both the achievement of the common agenda's collective outcome as well as the interests of each individual participant by preserving each participant's preferences and expectations.

A written agreement would also memorialize the flexibility desired for navigating these ongoing long-term relationships and the work required to address adaptive social problems. Long-term contracts are usually relational contracts and collective impact initiatives are designed to be long-term projects.

283. Macneil, supra note 203, at 662.

284. See generally Leib, supra note 223.

Most often, parties simply cannot allocate risks of their mutual endeavor at the start of a relationship because so much is uncertain, and so much trust-building is necessary to get the relationship off the ground. Indeed, the very incompleteness of the deal between the parties is central in defining what counts as a relational contract.

Id. at 675-76.

285. DiMatteo \& Morant, supra note 54, at 562.

286. See Kania et al., supra note 163. 
As such, a written agreement memorializing the intended long-term flexibility would more accurately reflect the parties' intent regarding the term and scope of the agreement.

All of this is not to suggest the use of written agreements in collective impact initiatives is completely absent, because that is not the case. ${ }^{287}$ However, the current use of collective impact agreements is too infrequent and those collective impact agreements that are executed are ill-structured documents for effectuating collective impact initiatives. For example, in some instances collective impact participants might rely on the initial grant agreement between the funder and the backbone agency. This is problematic. The grant agreement governs the award and administration of the grant and is an agreement between the funder and the backbone agency-most likely for the purpose of starting a collective impact initiative. There is no privity of contract between the funder and the nonbackbone participants in a collective impact working group. Equally as important, there is no privity of contract among the participants.

In another scenario, given the cooperative nature of collective impact agreements, ${ }^{288}$ it is hardly surprising participants unfamiliar with the formation and operation of business structures would gravitate to a document entitled "partnership agreement" as a model for collective impact agreements among the backbone and non-backbone participants. Anecdotal evidence suggests collective impact participants like to view these relationships as nonbusiness but strategic partnerships. Partnerships agreements, however, have a very distinct purpose and are designed to memorialize the legal obligations of parties who have intentionally decided to work in concert together for a for-profit purpose for their pecuniary gain. ${ }^{289}$ Partnership agreements govern, among other matters, the

287. In fact, this Author has analyzed a handful collective impact agreements provided to her for researching this Article. The next phase in this inquiry is an empirical one. Because there have been many more collective impact initiatives than executed collective impact agreements, much of the information in this Article is based on review of the few collective impact agreements the Author was able to find, information learned during interviews the Author conducted with certain individual either consulting on or participating in collective impact initiatives, and from anecdotal information.

288. Partners can, of course, contribute services to a partnership. That, however, is not a contract for an exchange of services but the provision of services by a partner to the partnership in exchange for equity or some other compensation from the partnership.

289. In early writings, Ian Macneil emphasized that humans desire both "solidarity and reciprocity," thus instilling a tendency to prefer relational contracts because a relational contract (1) can entail elements of discrete transactions enhancing independence and embodying choice; and (2) relational business dealings are more valuable for immediate and long-term monetary and social success than most pure discrete contracts with a stranger. Ian R. Macneil, Relational Contract Theory as Sociology: A Reply to Professors Lindenberg and de Vos, 143 J. Institutional \& TheOretical ECOn. 272, 274 (1987) [hereinafter Macneil, Relational Contract Theory as Sociology]. Further, Macneil focused on trade relationships and trade partnerships as examples of "social solidarity" where individuals can have a heightened sense of trust validated through "specialized reciprocity." Ian R. Macneil, Exchange Revisited: Individual Utility and Social 
partners' ownership interests in the partnership, the partners' levels of liability, and the partners' governance rights. It is not a contract for the exchange of services between parties. It may seem unnecessary to point this out where it seems clear from the language of the agreement the parties did not intend to participate in a partnership. However, this highlights an even more important point; like the construction industry, where there are four stages of practice that implicate where lawyers can use relational principles-planning, drafting agreements, oversight of project administration, and during dispute resolution-collective impact should have its own contracting process with its own set of documents. If participants across the country continue to borrow from various disciplines to meet their individual collective impact needs, it will stall the advancement of collective impact as a replicable model for social change by limiting the capacity for strategy study and development-becoming a lost opportunity for impact transaction.

\section{Public Policy}

Because collective impact initiatives directly affect members of the public, there are strong public policy reasons for using a written collective impact agreement. Unlike most private law transactions, collective impact initiatives are designed to address a particular social problem for the public good and, thus, collective impact agreements are contracts for the public interest. The seriousness of any potential to harm an underserved community warrants the imposition of more formalized collective impact agreement processes to increase the likelihood social change is actually advanced. Although the participants in collective impact initiatives may receive grant funds and attribution for their participation, the outcome of the initiative is ultimately for the benefit of the lives improved by the collective impact initiative's work. Thus, it is important to have collective impact agreements because, in most cases, there will be an identified third-party underserved community who will experience the initiative's outcome. These communities should not suffer harm because of an initiative's failure to execute a well-structured agreement.

Collective impact initiatives are built around relationships between social actors who coordinate expenditures and significant resources ranging from thousands to millions of dollars for services provided for the benefit of members of an underserved public. ${ }^{290}$ Given the amount of money invested in collective impact initiatives, the adoption of a more formal agreement-making process in the collective impact framework is necessary as a matter of transactional efficiency.

Solidarity, 96ETHICS 567,569(1986). Macneil focused on trading partnerships at very intricate and very low levels as examples of how humans have a penchant for relational contracts that is "ubiquitous as long as relations continue." Macneil, Relational Contract Theory as Sociology, supra note 289, at 284. Partnerships require engaging in "some give and take of information-a give which constitutes a form of mutual planning." Macneil, Futures, supra note 42, at 770.

290. See, e.g., ProjeCt U-TuRN, http://www.projectuturn.net/[https://perma.cc/PG5G-FQ9V] (last visited Mar. 4, 2016). 
Of course, having a written agreement does not solve all challenges. Although written agreements minimize certain risks inherent in collective impact initiatives, as discussed briefly in the next Part, other contract-related risks can arise once parties enter into a contract.

\section{CONTRACTING FOR COMPLEXITY: PlanNing FOR AND DRAFTING Collective Impact Agreements}

There are two important considerations to appreciate when contemplating a collective impact initiative: (1) the substance of the project (i.e., what is the designated social issue and who is the targeted population?); and (2) what are the services each member of the working group intends to provide to achieve the collective impact goal (i.e., what are the services to be exchanged among the working group?). This Part begins the discussion of facilitating impact transaction through collective impact by identifying relational contract drafting principles for a collective impact term sheet. Collective impact needs a contractual infrastructure. As collective impact is an emerging strategy, now is the right time to analyze its contract practices to develop form collective impact agreements that support a shared agenda for social change while providing for accountability and respecting the collective impact mindset.

\section{A. Collective Impact Agreements: Planning and Drafting for Flexibility}

Collective impact is a transactional framework for achieving "sustainable, scalable, systemic change." ${ }^{291}$ Before considering certain term sheet provisions that can advance that goal, this section outlines the profile of collective impact agreements because each component to the profile can impact the planning and drafting of collective impact agreements. As such, collective impact agreements are (1) multilateral (multi-party) (2) service agreements (3) between participants with diverse skill sets that are drafted to memorialize the parties' intent to affect social change for a specific underserved population through (4) synchronized and phased service delivery coordinated through long-term ongoing planning.

First, collective impact agreements are multilateral agreements, meaning they are agreements with more than two parties (or bilateral agreements). ${ }^{292}$ This distinction is important because multilateral agreements require special drafting considerations. ${ }^{293}$ One of the most significant of these considerations is ensuring the establishment of privity of contract between each of the parties to the collective impact agreement.

291. Sylvia Burwell, President of Glob. Develop., Bill \& Melinda Gates Found., Symposium Keynote Luncheon Address at the World Food Prize 2008 Norman E. Borlaug International Symposium (Oct. 16, 2008), available at https://www.worldfoodprize.org/documents/filelibrary/ images/borlaug_dialogue/2008_speakers/transcripts/burwell_717FA36A7A161.pdf [http://perma.cc/E63S-6ZPZ].

292. See, e.g., Bryce Johnson, Efficiency Concerns in Breach of Multilateral Contracts, 44 UCLA L. REV. 1513 (1997).

293. See generally id. 
Second, like the number of parties to the contract, the substance of the contract (what is being contracted for) will impact drafting considerations of collective impact agreements. Collective impact agreements are service contracts, meaning these are agreements for the exchange of services as opposed to the sale of goods. Contracts for services are inherently more relational than contracts for the sale of goods. ${ }^{294}$ This distinction warrants considerations in drafting operational provisions such as performance standards, as well as boilerplate provisions such as assignment provisions. ${ }^{295}$

Third, the next component to consider is the role of non-legal social enforcement in collective impact. Social norms as an enforcement mechanism is a signature characteristic of relational contracts. ${ }^{296}$ "Parties to relational contracts have learned to behave under two sets of rules: a strict set of rules for legal enforcement and a more flexible set of rules for social enforcement." ${ }^{297}$ To a large extent, collective impact relies on the emotional commitment of the participants. ${ }^{298}$ In collective impact, "community" is both the geographic and/or underserved targeted community around which the initiative is designed and all of the members of the collective impact initiative working group (and party to the collective impact agreement). ${ }^{299}$ It is here the social norm of trust is fostered and mechanisms such as dispute resolution are created. ${ }^{300}$

Fourth, planning is necessary for all contracting practices, but the notion that "[e]very contract is necessarily partially unplanned," 301 is particularly true for collective impact. Typically, planning around a discrete contract involves determining the parties' goals, the costs associated with those goals, and the methods for achieving those goals, including timelines. ${ }^{302}$ "Parties to a relational contract ... are likely to view the exchange as an ongoing integration of behavior which will grow and vary with events in a largely unforeseeable future."303

294. See Macneil, Futures, supra note 42, at 694.

295. "The principal task of the law of commercial contracts is to set default rules for commercial actors and other repeat players who, presumably, are quite capable of bargaining for customized alternatives." Robert E. Scott, A Relational Theory of Default Rules for Commercial Contracts, 19 J. Legal STUd. 597, 598 (1990).

296. See, e.g., Lisa Bernstein, Private Commercial Law in the Cotton Industry: Creating Cooperation Through Rules, Norms, and Institutions, 99 MicH. L. REv. 1724, 1725-28 (2001).

297. See Scott, supra note 295, at 615.

298. "It is a dedication to the philosophy of collective work, commitment to the common agenda, and willingness to leave your ego at the door." Fortunato, supra note 183.

299. See Barnes et al., supra note 193, at 12 (noting community also includes "social service organizations that may not be initially represented on steering committees or working groups").

300. "The termination of relational contracts engenders closer scrutiny. The duty to adjust or renegotiate, along with the norms of good faith and fair dealing, play more important roles, often non-legally induced." DiMatteo \& Morant, supra note 54, at 562.

301. Macneil, supra note 203, at 636.

302. See id. at 634.

303. Nestor M. Davidson, Relational Contracts in the Privatization of Social Welfare: The Case of Housing, 24 YALE L. \& POL'y ReV. 263, 281 (2006). 
Planning is fundamental to the execution of relational contracts and, in particular, collective impact agreements. ${ }^{304} \mathrm{~A}$ fundamental characteristic of contact planning is the distinction between performance planning and risk planning. ${ }^{305}$ Performance planning speaks to what tasks each party will perform to effectuate the agreement, the timeline by when these tasks should occur, and in accordance with what performance standards. Planning for risk allocation requires assessing which parties are in the best position either to minimize or withstand the risks associated with the transaction. ${ }^{306}$ In collective impact, planning dominates all other activities, as ongoing negotiated brainstorming occurs among the parties about the initiative.

\section{B. Drafting a Collective Impact Term Sheet}

The development of a sound contracting process that can provide replicable models for less resourced collective impact participants is important to the advancement of impact transaction. This Article begins that process. One of the goals of this Article is to make relational contract theory accessible and useful to practicing lawyers. Relational contract theory is far from undertheorized. It is, however, underutilized in practice because lawyers are under-informed about its applicability. ${ }^{307}$ Drafting relational contracts is not for the weak of heart. Good lawyers whose practice includes relational contracts will have to become "anthropologists, sociologists, economists, political theorists, and philosophers. ${ }^{308}$ This section begins the conversation about impact transaction contract principles by considering what sort of provisions might appear in a form collective impact term sheet. As collective impact advances as a strategy for social change, it will take time to normalize its contract practices. A collective impact term sheet is the first step of that normalization process.

A "term sheet" or "letter of intent" ${ }^{309}$ is a document that explores the possibility of a transaction. ${ }^{310}$ A term sheet demonstrates the parties'

304. "Relational contract theorists can win over adherents if contracts can be usefully mapped and ordered based on their relational elements . ..." Leib, supra note 223, at 661.

305. See id. Planning an exit strategy from the transaction is equally important.

306. See generally Scott, supra note 295, at 597.

307. " [T] here has not been enough effort made to tell lawyers how [relational contract theory] affects them. We say that the legal relationship is not the central thing; that there is this much more complex situation that you must understand if you wish to explain any contract. Relational Contracting in a Digital Age, supra note 48, at 690.

308. Leib, supra note 223, at 666 (citing Macneil, supra note 219, at 70); see also Circo, supra note 264, at 20-22 (explaining that "construction projects are highly relational" and listing the following roles for construction lawyers: (1) advising clients at the front end of a project; (2) continuing planning work; (3) counseling clients throughout project administration; and (4) advocating on behalf of clients to settle disputes).

309. Lawyers tend to use these terms interchangeably. This Article uses "term sheet."

310. See Vincent R. Martorana, Letters of Intent: What To Consider Before Your Deal Becomes a "Deal," COM.L. WeB ADVISOR, http://www.commerciallawwebadvisor.com/schedule/ 
psychological commitment to contract with each other. ${ }^{311}$ It is the preliminary step to a forthcoming agreement. Term sheets are intentionally vague documents designed to present the framework of a transaction, set forth binding and nonbinding provisions as such are related to the drafting and execution of the main agreement, acts as a thermometer for negotiations, forecasts the types of provisions that will be in the main agreement, and memorializes the distribution mechanism for payments or other forms of compensation. ${ }^{312}$ Term sheets are essential to the transactional planning process and can help avoid tensions that could arise later in the agreement-making process by putting all parties on notice that certain issues will be resolved at a later date. ${ }^{313}$ The use of term sheets is customary throughout transactional practice and their use as planning tools is particularly important for relational contracts such as collective impact agreements. ${ }^{314}$

There are building blocks common to all contract-types. Collective impact has yet to determine the building blocks of collective impact agreements because the collective impact agreement-making process is as novel as the collective impact framework itself, although much less frequently used. The use of a term sheet promotes better anticipation of the needs for an effective form collective impact agreement. Because collective impact is a nascent framework and the building blocks of collective impact agreements are unknown, this conversation about term sheets is important but also speculative. Term sheets are intended to help determine what is customary for certain types of agreement. An underlying goal for suggesting a collective impact term sheet is to start the conversation about impact transaction contract principles. Thus, for the purposes of this Article, the following term sheet concepts are the most salient: the preamble to the collective impact agreement; the identification of binding and nonbinding provisions to be included in the collective impact agreement; methods for dispute resolution; and mechanisms for tracking responsibility for performing conditions precedent under the collective impact agreement. Each of these is briefly discussed below.

Recitals and preambles in collective impact are important because of the unique nature of the relationship in the initiative. Despite the fact contracts are

detail/letters-of-intent--what-to-consider [perma.cc/APJ7-N93G] (last visited Mar. 4, 2016).

311. Id.

312. See generally Bruce Gibney, What's in a Term Sheet? The World's Most Irritating NotQuite-Contract, FoundER's Fund, http://web.archive.org/web/20130303042811/http://www. foundersfund.com/uploads/term_sheet_explained.pdf[https://perma.cc/K6CB-UUG7] (last visited Mar. 6, 2016).

313. See generally id.

314. Richard B. Potter, The Drafting and Enforcement of Canada/United States Contracts: A Canadian Lawyer's Perspective, 20 INT'LL. 3, 5 (1986) ("Because the relational contract is usually broader in scope and more complex than the traditional [discrete] contract, its negotiation is often a more lengthy process, the parties frequently want written evidence that the proposed transaction will indeed go forward, and this evidence is needed in advance of a formal signed contract."). 
not the "place to display literary style," 315 there are strong reasons for including language in collective impact agreement preambles that accurately reflects the parties' intent to have ongoing, fluid relationships based on trust. ${ }^{316}$ Such language would not only set the tone for the initiative, acting somewhat as a mission statement, but it would also serve to ground any new members to the initiative as well. In addition, it would also be helpful to communicate the initiative to other interested parties, including fact finders, who are not parties to the collective impact agreement.

When deciding whether to use a term sheet, the potential parties must consider which, if any, of the provisions in the term sheet should be binding. Because term sheets are designed as preliminary documents to encourage further negotiation, it is common practice for them to contain both binding and nonbinding provisions. Non-binding provisions are typically those that are not customary to a particularly type of transaction, whereas binding provisions are those that are customary to that type of transaction. An example appropriate for collective impact agreements would be the obligation of the parties to negotiate and proceed in good faith with fair dealing. Although this might not be necessary to accomplish anything under a collective impact agreement, like the preamble, it highlights the parties' expectations of each other's behavior. ${ }^{317}$

Given the collaborative intent of collective impact and its focus on relationship and enforcement via social norm mechanisms, it is not hard to imagine standard dispute resolution mechanisms being developed over the course of time for inclusion in a collective impact agreement. These would be appropriate provisions for a term sheet.

Finally, collective impact agreements are particularly tricky relational contracts and with shared agendas, come shared responsibilities. Although there are certainly multilateral arrangements that can serve as models for how to structure collective impact transactions, it is typically clear which party is responsible for what. In collective impact, however, the nature of the transaction is fluid and subject to change in many respects. This can make it difficult to track projects, including responsibility for existing projects and a willingness to take on new projects that might emerge. Naturally, it would be difficult to attempt to manage these ideas specifically with a term sheet; however, now is also the time for innovation and determining whether there is a mechanism that can preserve this idea in a term sheet for collective impact initiatives. ${ }^{318}$

315. Macneil, supra note 203, at 649.

316. See, e.g., ERTMAN, supra note 53 (discussing the unique intent of "flowery" language in donor and co-parenting agreements).

317. As compared to conventional contract doctrine, "relational contract is more committed to the duties of good faith and fair dealing, the significance of industry customs, and the availability of detrimental reliance remedies." See Circo, supra note 264, at 17.

318. As a highly relational industry, the construction industry might be illustrative here. Integrated Project Delivery and Master Services Agreements, in particular, might serve as good models. See, e.g., id. at 24. 


\section{Conclusion: Concerns, Predictions, And Next Steps}

"Contract law serves a number of purposes, including respect for private autonomy and consent-based obligations, enforcement of the moral obligation of promise, protection of reasonable expectation of the promise-receiving party, enhancement of social utility, and the general preservation of contractual relationships. ${ }^{\not 19}$ As such, well-drafted contracts are truly works of art. Contract orders both social and commercial relationships, functioning as both preferenceprotecting and preference-enhancing. ${ }^{320}$ This duality is particularly applicable to collective impact and is reflected in some of the counterarguments to this Article's proposal. Three of the strongest counterarguments are as follows:

1. Collective impact succeeds where trust among the participants is strong. The use of a formal agreement might be viewed as counter to this mindset of trust. The relational nature of the collective impact agreement, however, would enable the drafting of the agreement to be reflective of the collective impact mindset.

2. Similar to arguments Scott Cummings has made about the limitations of CED, collective impact might provide direct relief to underserved communities, but the framework does not necessarily address the larger social and political issues that have historically fostered inequity. Although collective impact is designed to foster large-scale social change, more research is required to assess how collective impact may be scaled up. However, there is nothing about the collective impact structure to suggest the framework cannot be used to advance public policy if the right parties formed a collective impact initiative. ${ }^{321}$

3. The formalization of the collective impact agreement process does not necessarily improve the opportunities for community engagement. As noted earlier, histories of exclusion will be repeated unless collective impact innovates with respect to expectations of community involvement. The fact most initiatives seem to be driven by funders, as opposed to coming from the community, supports allegations collective impact has a "grasstops" orientation as opposed to "grassroots." "322

The normalization of a form collective impact agreement is essential for the success of collective impact as the first impact transaction strategy. In addition to the above counterarguments, more empirical data and research is needed to answer other important questions about collective impact to test is

319. DiMatteo \& Morant, supra note 54, at 554-55.

320. See id. at 568 .

321. See Thaddeus Ferber \& Erin White, Making Public Policy Collective Impact Friendly in COLLECTIVE Insights on COLLECTIVE IMPACT 22-23 (2014), available at http://ssir.org/articles/ entry/making_public_policy_collective_impact_friendly [https://perma.cc/9MHV-ARTH].

322. See Kania et al., supra note 163. 
appropriateness for impact transaction. First, as it currently operates, collective impact is largely a private law matter, but perhaps there is a role for the state to play in the pursuit of equity. Perhaps the state could deploy or require mechanisms for oversight or assessment of collective impact initiatives, regulate the substance of certain provisions in the form collective impact agreement, or create a ratings system for backbone agencies. Next, what is the appropriate cost benefit analysis to determine whether collective impact initiatives are working and/or sustainable? Moreover, how do we learn whether collective impact is only appropriate for social types of social problems, beyond the adaptive versus technical distinction? For example, will economic development collective impact initiatives consistently be as successful as the nationally replicated educationfocused initiatives? Finally, what is the role of the lawyer in collective impact? Parties to multi-lateral commercial contracts are typically represented by independent counsel. This is highly unlikely for collective impact agreements, forcing the fundamental professional ethics question: who is the client? ${ }^{323}$

Despite these counter arguments, collective impact has a lot of potential. As the framework continues to grow in popularity, it will be important to create mechanisms for assessment. ${ }^{324}$

If successful [the collective impact evolution] presages the spread of a new approach that will enable us to solve today's most serious social problems with the resources we already have at our disposal. It would be a shock to the system. But, it's a form of shock therapy that's badly needed. ${ }^{325}$

323. This is a common question for lawyers working with multiple owners in the formation of for-profit entities. Generally speaking, for small businesses and start-ups, the idea of independent counsel for each owner is a financial impossibility, and the lawyer must decide how to move forward with the representation by clearly identifying the client and getting the explicit consent of all of the owners to move forward with the representation.

324. See Parkhurst \& Preskill, supra note 162.

325. Kania \& Kramer, supra note 79 , at 41. 